Prepared in cooperation with the National Park Service

\title{
Sand Creek Characterization Study for Oncorhynchus clarkii virginalis (Rio Grande Cutthroat Trout), Great Sand Dunes National Park and Preserve, Colorado
}

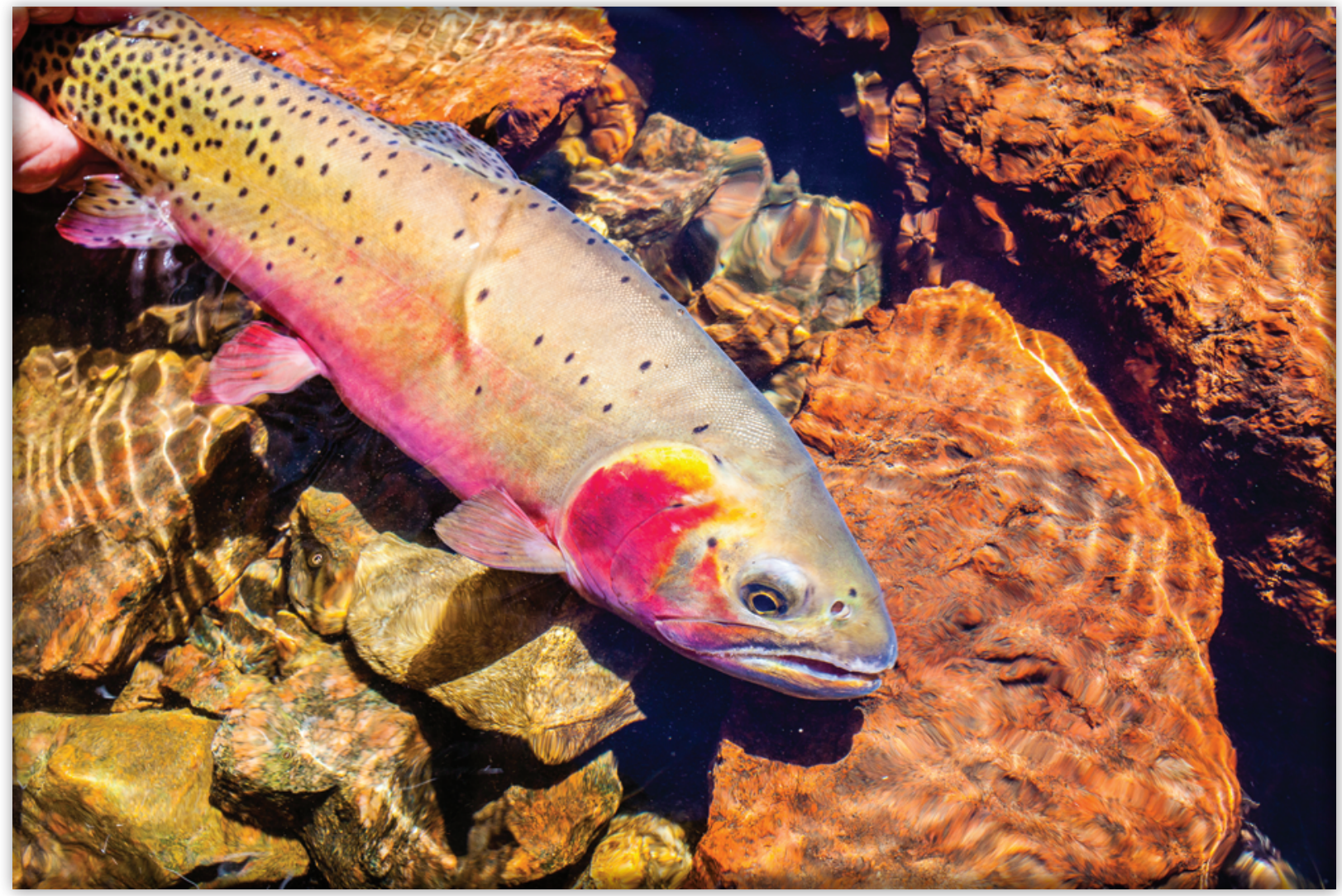

Scientific Investigations Report 2019-5061 
Cover. Image of a cutthroat trout captured in Upper Sand Creek Lake on August 1, 2017, Great Sand Dunes National Park and Preserve, Colorado. Photograph courtesy of Erik Myhre, Basin + Bend, Evergreen Colo. Used with permission. 


\section{Sand Creek Characterization Study for Oncorhynchus clarkii virginalis (Rio Grande Cutthroat Trout), Great Sand Dunes National Park and Preserve, Colorado}

By Ben N. McGee, Andrew S. Todd, and Kevin K. Terry

Prepared in cooperation with the National Park Service

Scientific Investigations Report 2019-5061 


\title{
U.S. Department of the Interior \\ DAVID BERNHARDT, Secretary
}

\author{
U.S. Geological Survey \\ James F. Reilly II, Director
}

U.S. Geological Survey, Reston, Virginia: 2019

For more information on the USGS - the Federal source for science about the Earth, its natural and living resources, natural hazards, and the environment-visit https://www.usgs.gov or call 1-888-ASK-USGS.

For an overview of USGS information products, including maps, imagery, and publications,

visit https://store.usgs.gov.

Any use of trade, firm, or product names is for descriptive purposes only and does not imply endorsement by the U.S. Government.

Although this information product, for the most part, is in the public domain, it also may contain copyrighted materials as noted in the text. Permission to reproduce copyrighted items must be secured from the copyright owner.

Suggested citation:

McGee, B.N., Todd, A.S., and Terry, K.A., 2019, Sand Creek characterization study for Oncorhynchus clarkii virginalis (Rio Grande cutthroat trout), Great Sand Dunes National Park and Preserve, Colorado: U.S. Geological Survey Scientific Investigations Report 2019-5061, 38 p., https://doi.org/10.3133/sir20195061.

ISSN 2328-0328 (online) 


\section{Acknowledgments}

The authors would like to thank Fred Bunch, National Park Service, who made this

characterization study possible. His efforts championed the necessary resources and personnel to reclaim Great Sand Dunes National Park and Preserve for native Oncorhynchus clarkii virginalis (Rio Grande cutthroat trout). We would also like to recognize the field personnel and aquatic biologists from Colorado Parks and Wildlife for their time and effort in developing a treatment plan and carrying out a resource-intensive reclamation for Rio Grande cutthroat trout in the Sand Creek watershed. We are thankful for the hard work and dedication of Trout Unlimited in protecting native fish; our future generations will be thankful too. In addition, we greatly appreciate the field personnel and aquatic ecologists from Colorado Department of Public Health and Environment. The benthic macroinvertebrate sampling they carried out in extremely remote areas of this watershed helped support this characterization study and strengthen this report.

We gratefully acknowledge the work and analyses of John Wood, Pisces Molecular, LLC, in Boulder, Colorado. The genetic composition and eDNA portions of this report are critical to Great Sand Dunes National Park and Preserve and Colorado Parks and Wildlife decisionmaking. 


\section{Contents}

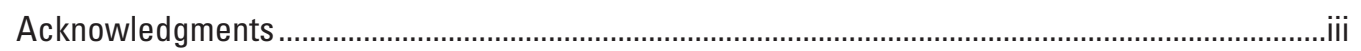

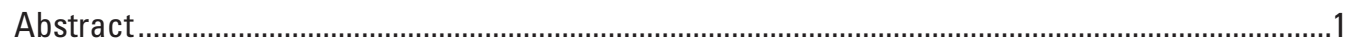

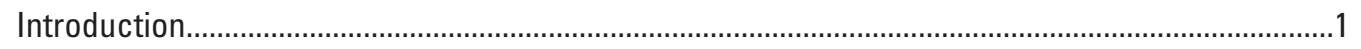

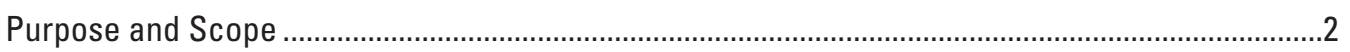

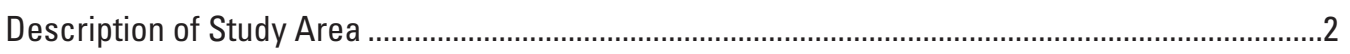

Rio Grande Cutthroat Trout Background Information .............................................................

Current Rio Grande Cutthroat Trout Management Across its Historical Range .......................6

Rio Grande Cutthroat Trout Biology and Habitat Requirements ................................................

Threats to Rio Grande Cutthroat Trout Persistence ...................................................................

A Brief History of Sand Creek Property Ownership and Fisheries Management......................

Great Sand Dunes National Park and Preserve Sand Creek Restoration Planning ..................7

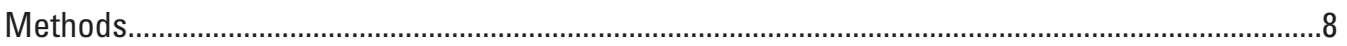

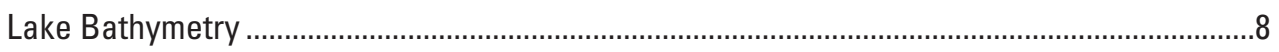

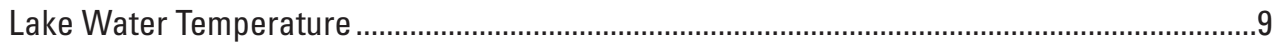

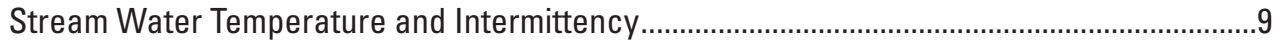

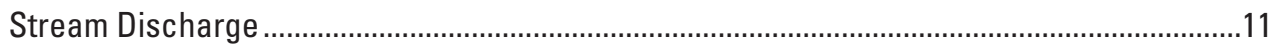

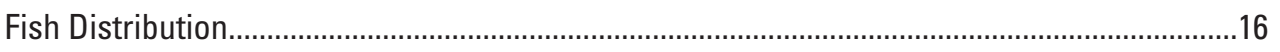

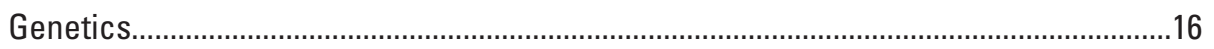

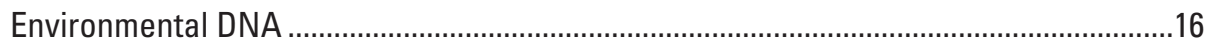

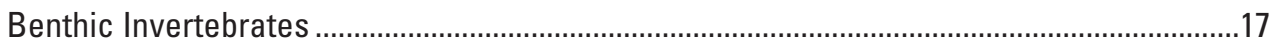

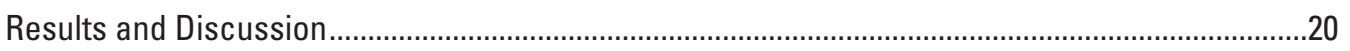

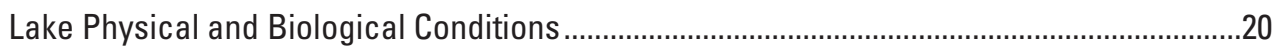

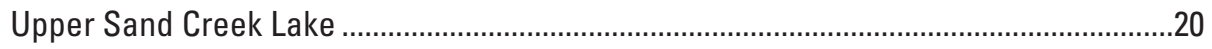

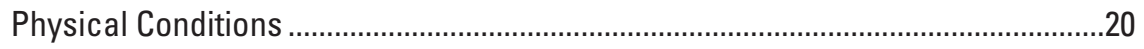

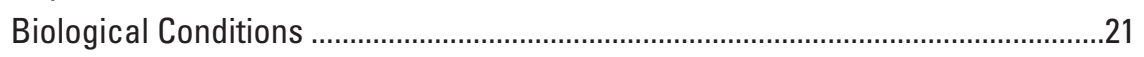

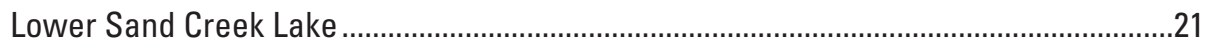

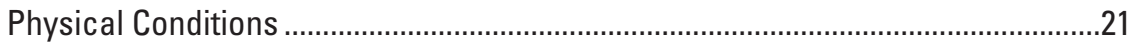

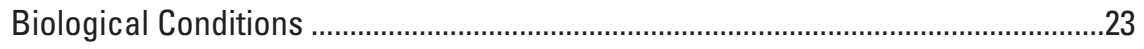

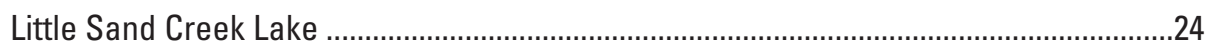

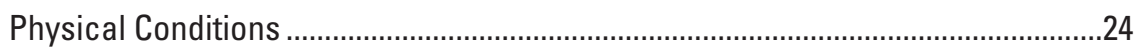

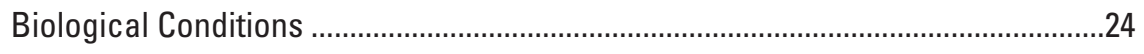

Mainstem Sand Creek Stream Physical and Biological Conditions.........................................26

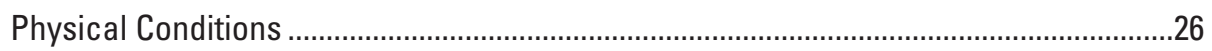

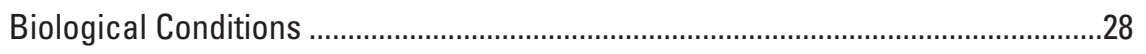

Tributaries to Sand Creek Physical and Biological Conditions ................................................28

Upper Sand Creek Lake Outlet Creek (Sites USL1 and USL2) ........................................28

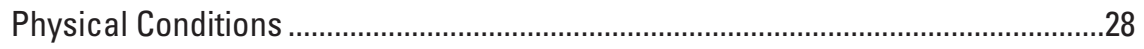

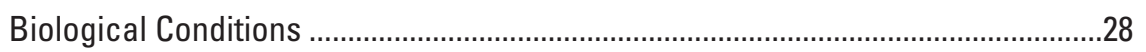

Lower Sand Creek Lake Outlet Creek (Sites LSL1 and LSL2) .........................................30

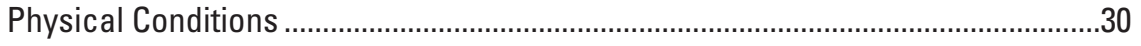

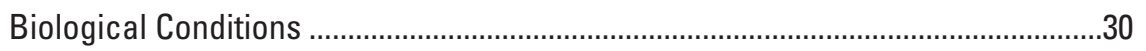

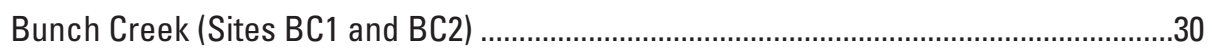

Physical Conditions ……............................................................................... 


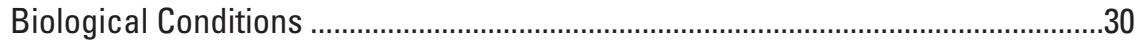

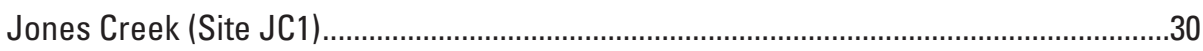

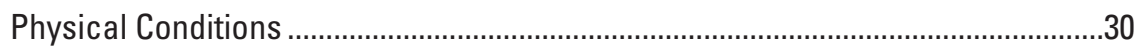

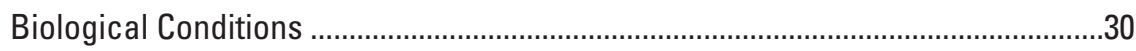

Little Sand Creek (Sites LSC1, LSC2, LSC3, and LSC4) ...................................................

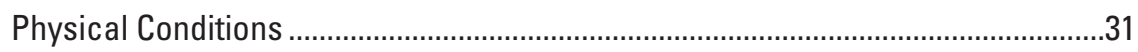

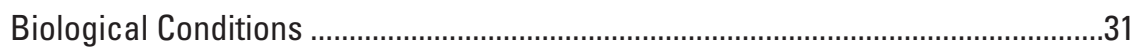

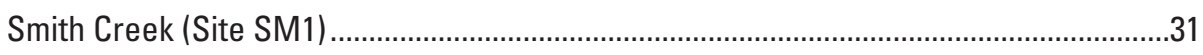

Physical Conditions ……...................................................................................

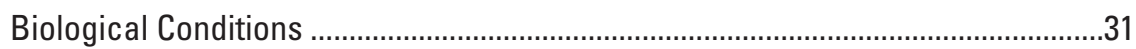

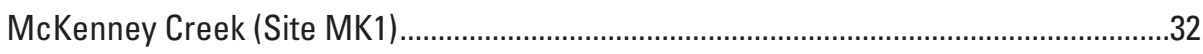

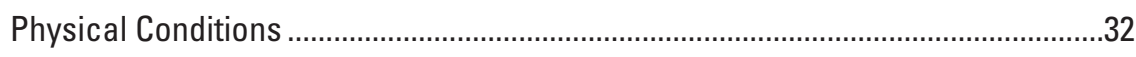

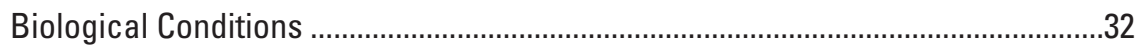

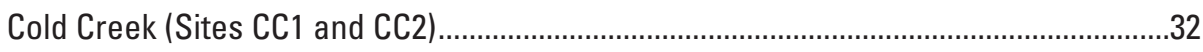

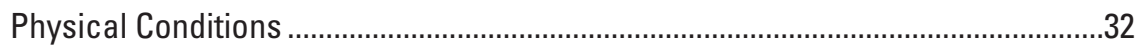

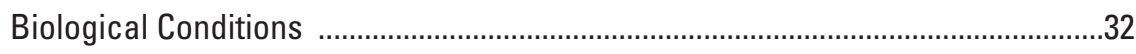

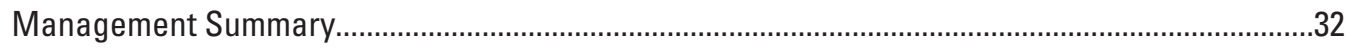

Lakes that are Good Candidates for Reclamation and Reintroduction of RGCT .....................33

Lakes that are Poor Candidates for Reclamation......................................................................33

Streams that Currently Have Fish and are Good Candidates for Reclamation and

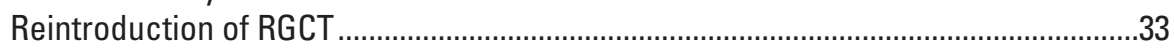

Streams that Currently Lack Fish and may be Good Candidates for Introduction of RGCT ...33

Streams that Currently Lack Fish and are not Good Candidates for Introduction of RGCT ...34

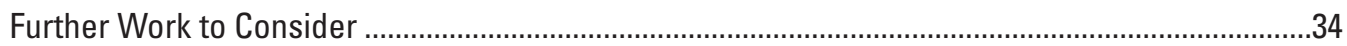

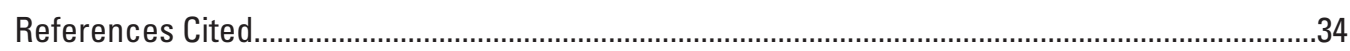

Appendix 1. Summary of Cutthroat Trout Amplified Fragment Length Polymorphism (AFLP)

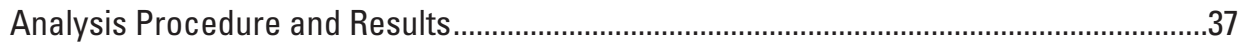

Reference Cited................................................................................................................. 


\section{Figures}

1. Imagery of Great Sand Dunes National Park and Preserve, Colorado, with Park and Preserve boundaries, along with the watershed boundary of Sand Creek.

2. Digitally enhanced imagery of key stream features within the Sand Creek watershed. Major stream features in the watershed include mainstem Sand Creek, Bunch Creek, Jones Creek, Little Sand Creek, McKenney Creek, Smith Creek, and Cold Creek

3. Digitally enhanced imagery of key lake features within the Sand Creek watershed. Lake features in the Sand Creek watershed include Upper Sand Creek Lake, Lower Sand Creek Lake, the larger, easternmost of the Little Sand Creek Lakes, and informally named Bunch Lake....

4. Digitally enhanced imagery of stream temperature, intermittency, and conductivity (STIC) monitoring sites within the Sand Creek. Loggers were distributed spatially within the watershed to characterize the thermal regime of mainstem Sand Creek and several other perennial tributaries

5. Digitally enhanced imagery of the flow measurement sites within the Sand Creek watershed. Discharge measurements were recorded during the 2014 and 2015 field seasons to understand available habitat and estimate resources required for treatment.

6. Digitally enhanced imagery of environmental deoxyribonucleic acid (eDNA) sampling sites within the Sand Creek watershed. Environmental DNA (eDNA) samples were taken in support of electrofishing surveys to determine the presence or absence of fish.

7. Digitally enhanced imagery of benthic macroinvertebrate (BMI) sampling sites within the Sand Creek watershed. Historical BMI sampling was primarily focused in the upper watershed and mainstem of Sand Creek, with most sample sites falling inside the defined treatment zone

8. Bathymetric profile of Upper Sand Creek Lake. Bathymetry and seasonal stratification profiles are helpful in preparation for piscicide treatment of lentic environments

9. Thermocline graph of Upper Sand Creek Lake shows a strong thermal stratification for most months that the lake is ice free..

10. Histogram of genetic composition of the fish population within Upper Sand Creek Lake. Individual fin clips collected from 30 captured fish were analyzed using amplified fragment length polymorphism (AFLP) tests to distinguish genetic admixture or purity

11. Photographs of two individual fish captured in Upper Sand Creek Lake sampled for genetic analyses.

12. Bathymetric profile of Lower Sand Creek Lake. Bathymetry and seasonal stratification profiles are helpful in preparation for piscicide treatment of lentic environments

13. Thermocline graph of Lower Sand Creek Lake shows a strong thermal stratification for most months that the lake is ice free.

14. Histogram of genetic composition of the fish population within Lower Sand Creek Lake. Individual fin clips collected from 30 captured fish were analyzed using amplified fragment length polymorphism (AFLP) tests to distinguish genetic admixture or purity

15. Photographs of two individual fish captured in Lower Sand Creek Lake and sampled for genetic analyses 
16. Genetic composition of three fish sampled at Little Sand Creek Lake (LSL-01, LSL-02, and LSL-03), compared statistically to the genetic composition of Upper Sand Creek Lake (USCL-01 through USCL-30). Individual fin clips collected from three captured fish were analyzed using amplified fragment length polymorphism (AFLP) tests to distinguish genetic admixture or purity.

17. Graph of water temperature data collected in 2014, 2015, and 2016 from mainstem Sand Creek. The maximum weekly average temperature (MWAT) is a useful biological metric for estimating habitat suitability and successful recruitment for Oncorhynchus clarkii virginalis (Rio Grande cutthroat trout,

RGCT)

\section{Tables}

1. Stream temperature, intermittency, and conductivity (STIC) logger site

descriptions, abbreviated site names, and geographic locations . . .12

2. Summary of stream temperature metrics from mainstem Sand Creek and tributaries measured in 2014 through 2016.

3. A summary for baseflow stream discharge measured in August 2014 and 2015, within the Sand Creek watershed.

4. A summary of fish distribution data collected from visual observation, backpack electrofishing, and eDNA sampling.... 


\section{Conversion Factors and Datums}

U.S. customary units to International System of Units

\begin{tabular}{|c|c|c|}
\hline Multiply & By & To obtain \\
\hline \multicolumn{3}{|c|}{ Length } \\
\hline inch (in.) & 25.4 & millimeter $(\mathrm{mm})$ \\
\hline foot $(\mathrm{ft})$ & 0.3048 & meter $(\mathrm{m})$ \\
\hline mile (mi) & 1.609 & kilometer (km) \\
\hline yard (yd) & 0.9144 & meter $(\mathrm{m})$ \\
\hline \multicolumn{3}{|c|}{ Area } \\
\hline acre & 4,047 & square meter $\left(\mathrm{m}^{2}\right)$ \\
\hline acre & 0.4047 & hectare (ha) \\
\hline acre & 0.4047 & square hectometer $\left(\mathrm{hm}^{2}\right)$ \\
\hline acre & 0.004047 & square kilometer $\left(\mathrm{km}^{2}\right)$ \\
\hline square mile $\left(\mathrm{mi}^{2}\right)$ & 259.0 & hectare (ha) \\
\hline square mile $\left(\mathrm{mi}^{2}\right)$ & 2.590 & square kilometer $\left(\mathrm{km}^{2}\right)$ \\
\hline \multicolumn{3}{|c|}{ Volume } \\
\hline cubic foot $\left(\mathrm{ft}^{3}\right)$ & 0.02832 & cubic meter $\left(\mathrm{m}^{3}\right)$ \\
\hline acre-foot (acre-ft) & 1,233 & cubic meter $\left(\mathrm{m}^{3}\right)$ \\
\hline \multicolumn{3}{|c|}{ Flow rate } \\
\hline cubic foot per second $\left(\mathrm{ft}^{3} / \mathrm{s}\right)$ & 0.02832 & cubic meter per second $\left(\mathrm{m}^{3} / \mathrm{s}\right)$ \\
\hline
\end{tabular}

International System of Units to U.S. customary units

\begin{tabular}{lll}
\hline \multicolumn{1}{c}{ Multiply } & By & \multicolumn{1}{c}{ To obtain } \\
\hline centimeter $(\mathrm{cm})$ & Length & inch (in.) \\
millimeter $(\mathrm{mm})$ & 0.3937 & inch (in.) \\
meter $(\mathrm{m})$ & 0.03937 & foot $(\mathrm{ft})$ \\
kilometer $(\mathrm{km})$ & 3.281 & mile (mi) \\
meter $(\mathrm{m})$ & 0.6214 & yard $(\mathrm{yd})$ \\
\hline & 1.094 & \\
\hline square meter $\left(\mathrm{m}^{2}\right)$ & Area & acre \\
hectare $(\mathrm{ha})$ & 0.0002471 & acre \\
hectare $(\mathrm{ha})$ & 2.471 & square mile $\left(\mathrm{mi}^{2}\right)$ \\
square kilometer $\left.(\mathrm{km})^{2}\right)$ & 0.003861 & square mile $\left(\mathrm{mi}^{2}\right)$ \\
\hline & 0.3861 & gallon $(\mathrm{gal})$ \\
\hline liter $(\mathrm{L})$ & Volume & \\
\hline & 0.2642 & foot per second $(\mathrm{ft} / \mathrm{s})$ \\
\hline meter per second $(\mathrm{m} / \mathrm{s})$ & Flow rate & cubic foot per second $\left(\mathrm{ft}^{3} / \mathrm{s}\right)$ \\
cubic meter per second $\left(\mathrm{m}^{3} / \mathrm{s}\right)$ & 3.281 & mile per hour $(\mathrm{mi} / \mathrm{h})$ \\
kilometer per hour $(\mathrm{km} / \mathrm{h})$ & 35.31 & ounce, avoirdupois $(\mathrm{oz})$ \\
\hline
\end{tabular}

Temperature in degrees Celsius $\left({ }^{\circ} \mathrm{C}\right)$ may be converted to degrees Fahrenheit $\left({ }^{\circ} \mathrm{F}\right)$ as

$$
{ }^{\circ} \mathrm{F}=\left(1.8 \times{ }^{\circ} \mathrm{C}\right)+32 .
$$

Temperature in degrees Fahrenheit $\left({ }^{\circ} \mathrm{F}\right)$ may be converted to degrees Celsius $\left({ }^{\circ} \mathrm{C}\right)$ as

$$
{ }^{\circ} \mathrm{C}=\left({ }^{\circ} \mathrm{F}-32\right) / 1.8 \text {. }
$$




\title{
Datums
}

Vertical coordinate information is referenced to the Universal Transverse Mercator (UTM), North American Datum of 1983 (NAD83).

Horizontal coordinate information is referenced to the Universal Transverse Mercator (UTM), North American Datum of 1983 (NAD83).

\section{Abbreviations}

\author{
AFLP Amplified fragment length polymorphism \\ BRK Salvelinus fontinalis (brook trout) \\ BMI Benthic macroinvertebrate \\ CDOW Colorado Division of Wildlife \\ CDPHE Colorado Department of Public Health and Environment \\ CPW Colorado Parks and Wildlife \\ CRCT Oncorhynchus clarkii pleuriticus (Colorado River cutthroat trout) \\ CUTT General cutthroat trout with known or unknown genetic admixture \\ CWOCC Colorado Water Quality Control Commission \\ DM Daily maximum temperature \\ DOI U.S. Department of the Interior \\ eDNA Environmental deoxyribonucleic acid \\ ER Electrical resistence \\ GBCT Oncorhynchus clarkii stomias (greenback cutthroat trout) \\ GRSA Great Sand Dunes National Park and Preserve \\ MMI Macroinvertebrate multi-metric index \\ MWAT Maximum weekly average temperature \\ NPS U.S. National Park Service \\ PECE Policy for Evaluation of Conservation Efforts \\ RBT Oncorhynchus mykiss (rainbow trout) \\ RC Relative conductivity \\ RGCT Oncorhynchus clarkii virginalis (Rio Grande cutthroat trout) \\ STIC Stream temperature, intermittency, and conductivity logger \\ USFWS U.S. Fish and Wildlife Service \\ USGS U.S. Geological Survey \\ YSCT Oncorhynchus clarkii bouvieri (Yellowstone cutthroat trout)
}





\title{
Sand Creek Characterization Study for Oncorhynchus clarkii virginalis (Rio Grande Cutthroat Trout), Great Sand Dunes National Park and Preserve, Colorado
}

\author{
By Ben N McGee, ${ }^{1}$ Andrew S. Todd ${ }^{2}$ and Kevin K. Terry ${ }^{3}$
}

\section{Abstract}

The Oncorhynchus clarkii virginalis (Rio Grande cutthroat trout, RGCT) has undergone extensive declines in distribution and population. The RGCT is the southernmost distributed subspecies of cutthroat trout. Native to the Rio Grande Basin in Colorado and New Mexico, the subspecies is also found in the headwaters of the Pecos River and Canadian River basins in New Mexico. Currently, RGCT populations represent approximately 12 percent of the historic distribution. There are many factors that have contributed to the decline of the RGCT including small population sizes; hybridization with non-native salmonids; competition with non-native salmonids; angling; and loss of habitat resulting from wildfire, stream drying, disease, increased water temperatures; and poor land management.

The eastern side of Colorado's Rio Grande Basin is also home to Great Sand Dunes National Park and Preserve and the Sand Creek watershed. This study was designed to (1) characterize current physical and biological conditions of waterbodies within the Sand Creek watershed, from headwaters to lower terminus near the dune field; (2) characterize the spatial extent of existing fisheries within the Sand Creek watershed to inform the scope of potential future reclamation efforts; and (3) evaluate key limiting factors for a future native RGCT reintroduction.

Bathymetric profiles were completed for two lakes within the upper Sand Creek drainage to characterize the physical geometry of each lake and to estimate the total lake volume required for future piscicide treatment and (or) fish removal efforts. Physical and biological conditions evaluated included stream water temperature and intermittency, discharge, and the genetics and existing fish community distribution and composition within the Sand Creek watershed were key components of this study. A baseline established the geographic extent and biological constraints factored into future piscicide treatment planning and native trout reintroduction efforts.

\footnotetext{
${ }^{1}$ U.S. Geological Survey

${ }^{2}$ U.S. Environmental Protection Agency

${ }^{3}$ Trout Unlimited
}

As a result of this work, the Sand Creek watershed can be broken up into several distinct categories: Lakes that are good candidates for reclamation and reintroduction of RGCT, lakes that are poor candidates for reclamation, streams that currently have fish and are good candidates for reclamation and reintroduction, streams that currently lack fish and may be good candidates for introduction of RGCT, and streams that currently lack fish and are not good candidates for introduction of RGCT. This characterization study report is intended to inform State and Federal managers of the likelihood that the Sand Creek watershed can support a sustainable population of RGCT should they be reintroduced.

\section{Introduction}

As a part of the Great Sand Dunes National Park and Preserve (GRSA) mission to restore native plant and animal species, the Sand Creek watershed presents a unique opportunity for anglers and park visitors to have a recreational population of native Oncorhynchus clarkii virginalis (Rio Grande cutthroat trout, RGCT) (NPS, 2006). Historically, the RGCT has seen extensive declines in distribution and population in recent decades. Currently, RGCT populations represent approximately 12 percent of the historical distribution (Alves and others, 2008). Many factors have contributed to the decline of the RGCT including small population sizes, hybridization with non-native salmonids, competition with non-native salmonids, loss of habitat resulting from wildfire, stream drying, disease, increased water temperatures, poor land management, and angling (Pritchard and Cowley, 2006; U.S. Fish and Wildlife Service [USFWS], 2014a). The RGCT is not currently listed for Federal protection under the Endangered Species Act (ESA) of 1973 (16 U.S.C. $\$ 1531$ et seq. [1973]). A key factor to the USFWS's recent decision that listing the RGCT is not warranted was due to the specific conservation actions and timeline identified in the Rio Grande Cutthroat Trout Conservation Strategy of 2013 (Rio Grande Cutthroat Trout [RGCT] Conservation Team, 2013), but because of these declines, Colorado wildlife managers are 
Sand Creek Characterization Study for Cutthroat Trout, Great Sand Dunes National Park and Preserve, Colo.

taking protective measures for RGCT as a Species of Special Concern (USFWS, 2014c).

Sand Creek, a perennial stream basin on the northern perimeter of GRSA, was evaluated in this report to determine if its watershed could provide abundant suitable habitat for a robust and sustainable population of RGCT (fig. 1). This study was designed to characterize current physical and biological conditions of waterbodies and streams within the Sand Creek watershed, from headwaters to lower terminus near the dune field, so wildlife managers can determine the likelihood of success if Sand Creek were to be reclaimed for RGCT, and to help wildlife managers define the scope of the potential treatment zone.

\section{Purpose and Scope}

Past efforts to characterize the watershed include Colorado Parks and Wildlife (CPW) information on fish density and distribution for recreational purposes, and inventory of macroinvertebrates for ecological health purposes (Zuellig and others, 2006). However, the details necessary for a basin-wide reclamation were generally lacking. A robust and thorough characterization with multiple years of data collection is critical for GRSA decisionmaking purposes.

Initially, this study was designed to characterize the spatial extent of existing fisheries within the Sand Creek watershed to inform the scope of potential future reclamation efforts. Several lines of evidence were utilized (visual observation, hook and line sampling, electrofishing, and environmental deoxyribonucleic acid [eDNA] testing) to evaluate the present or absent status of fisheries of all perennial waters within the Sand Creek watershed. On select identified fisheries (that is, Upper and Lower Sand Creek Lakes), genetic analyses were carried out to determine the level of genetic introgression with non-RGCT species.

Additional components of this work were designed to measure key physical attributes of waterbodies in the Sand Creek watershed with the dual purposes of identifying future habitat suitability and informing future reclamation efforts. On the reclamation front, discharge at or near baseflow and lake bathymetry were measured to inform future treatment logistics and associated cost estimates. Related to future fish habitat suitability, streamflow permanence and water temperature were key metrics evaluated.

\section{Description of Study Area}

The Sand Creek watershed is located on the eastern side of Colorado's San Luis Valley in the Sangre de Cristo Mountains (fig. 1). The headwaters of Sand Creek flow southeast and eventually to the southwest along the northern boundary of the dune field at GRSA before depositing water in the San Luis Lakes during high flow periods in wet years or infiltrating into the aquifer of the San Luis Valley's closed basin in low flow periods and dry years. The approximate calculated watershed drainage area from the confluence of Sand Creek and Cold Creek is 32 square miles $\left(\mathrm{mi}^{2}\right)$ with an estimated annual mean flow of 18.8 cubic feet per second $\left(\mathrm{ft}^{3} / \mathrm{s}\right)$ according to USGS StreamStats (USGS, 2019). Figure 2 illustrates key stream features within the watershed.

The upper portion of the watershed is characterized by significant glacial activity, with two cirque lakes located in the headwaters (Upper and Lower Sand Creek Lakes) that outflow via streams flowing through granite bedrock with steep stream gradients and waterfalls. These lake-fed tributaries then join the mainstem of Sand Creek, which flows through a confined valley with limited floodplain connectivity. Figure 3 illustrates key lake features within the watershed.

Sand Creek is joined by several perennial tributaries including Jones Creek, Little Sand Creek, McKenney Creek, Smith Creek, and the informally named Bunch Creek. Several ephemeral tributaries seasonally contribute to the Lower Sand Creek watershed, including Sliderock Canyon, Cleveland Gulch, and Cold Creek (fig. 2). The sole streamgage in the watershed (Sand Creek at Great Sand Dunes National Park [SANDUNCO]) is located on the mainstem of Sand Creek just above the confluence with Cold Creek and is maintained by NPS and the Colorado Division of Water Resources (fig. 1).

\section{Rio Grande Cutthroat Trout Background Information}

The RGCT is the southernmost distributed subspecies of cutthroat trout. Native to the Rio Grande Basin in Colorado and New Mexico, these fish are also found in the headwaters of the Pecos River and Canadian River basins in New Mexico. The RGCT was the first trout in North America to be encountered by Europeans in 1541 during the expedition led by Francisco de Coronado, and it was formally described in 1856 from specimens collected from Ute Creek during a railroad survey in 1853 on the eastern side of the San Luis Valley near Ft. Garland, Colorado (Girard, 1857). The RGCT originated from the Oncorhynchus clarkii pleuriticus (Colorado River cutthroat trout, CRCT) which derived from the Oncorhynchus clarkii bouvieri (Yellowstone cutthroat trout, YSCT) lineage (Behnke, 1992, 2002). The RGCT is genetically more differentiated from the Colorado River cutthroat trout than the Oncorhynchus clarkii stomias (greenback cutthroat trout, GBCT), indicating that the Rio Grande fish branched off at an earlier time than the Greenback cutthroat trout which is native to the South Platte drainage in Colorado (Behnke, 2002).

The RGCT displays significant phenotypic variance across its historic range, which is most evident in the Pecos strain as compared to fish occupying streams of the Rio Grande Basin. The RGCT is characterized by large spots, often concentrated on the caudal peduncle and above the lateral line. RGCT display colorations from bright crimson red 


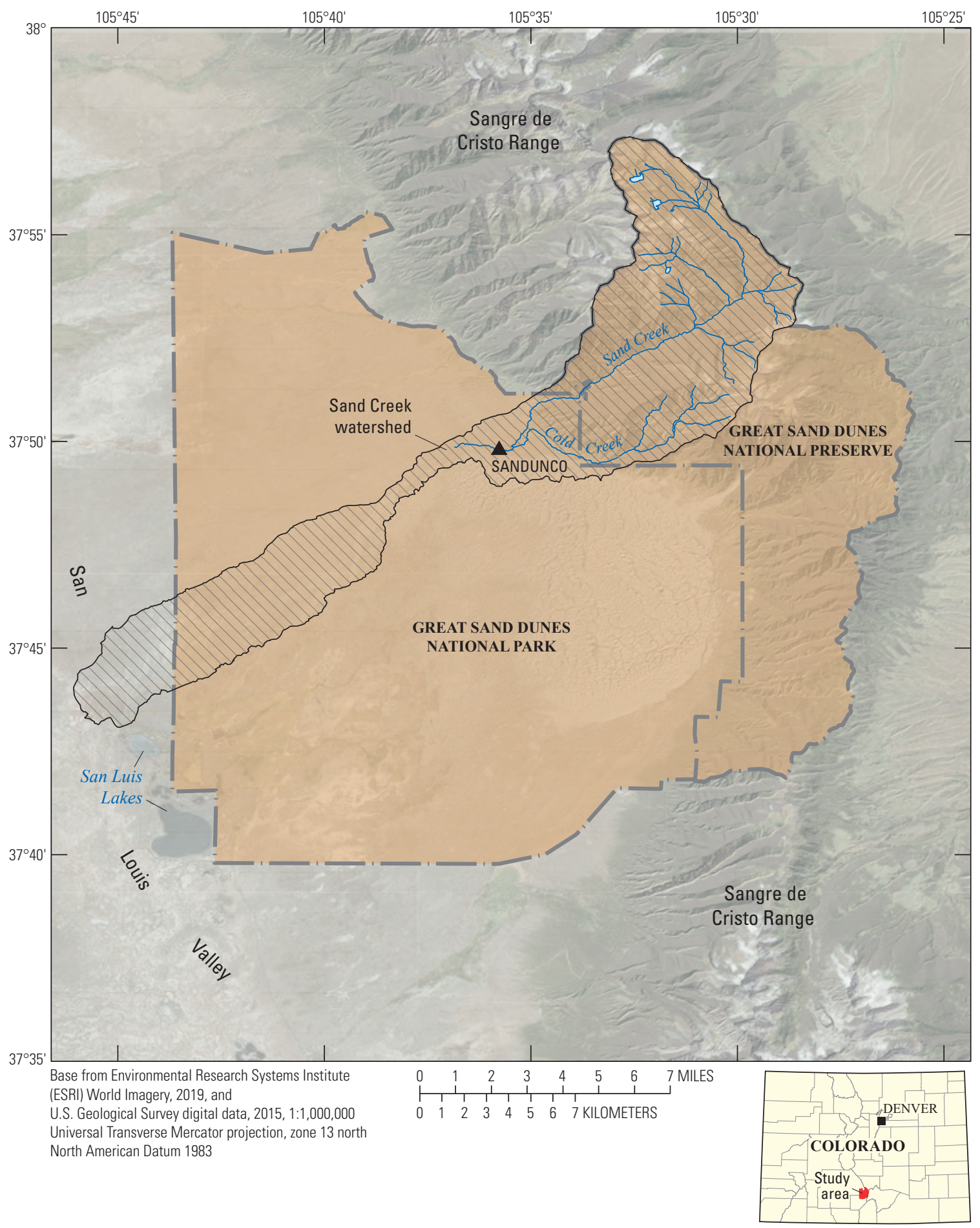

Figure 1. Imagery of Great Sand Dunes National Park and Preserve, Colorado, with Park and Preserve boundaries, along with the watershed boundary of Sand Creek. Triangle is streamgaging station SANDUNCO. 


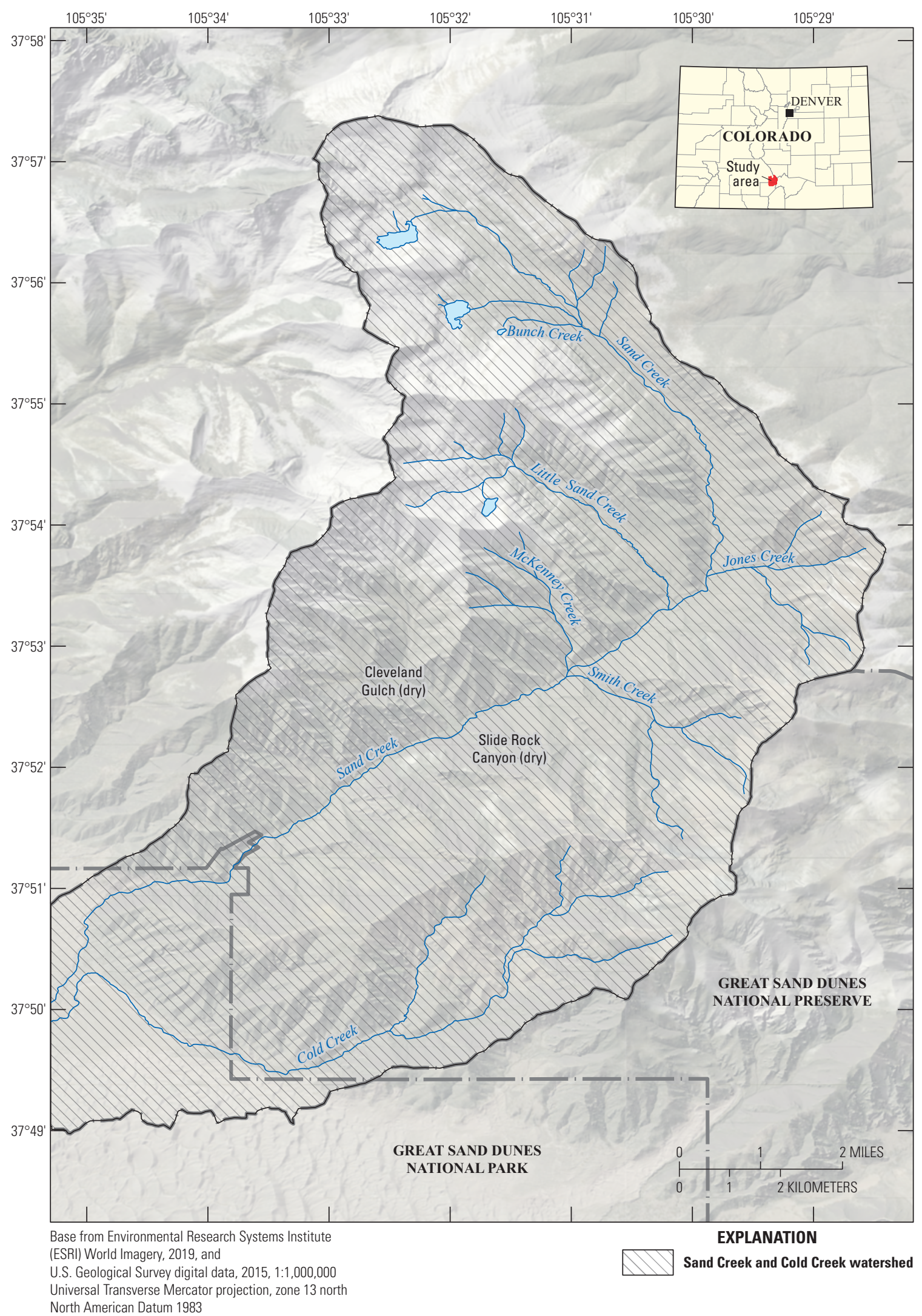

Figure 2. Digitally enhanced imagery of key stream features within the Sand Creek watershed, Great Sand Dunes National Park and Preserve, Colorado. Major stream features in the watershed include mainstem Sand Creek, Little Sand Creek, and Cold Creek. Other perennial tributaries include Upper Sand Creek Lake outlet creek, Lower Sand Creek Lake outlet creek, Jones Creek, McKenney Creek, Smith Creek, and the informally named Bunch Creek. 


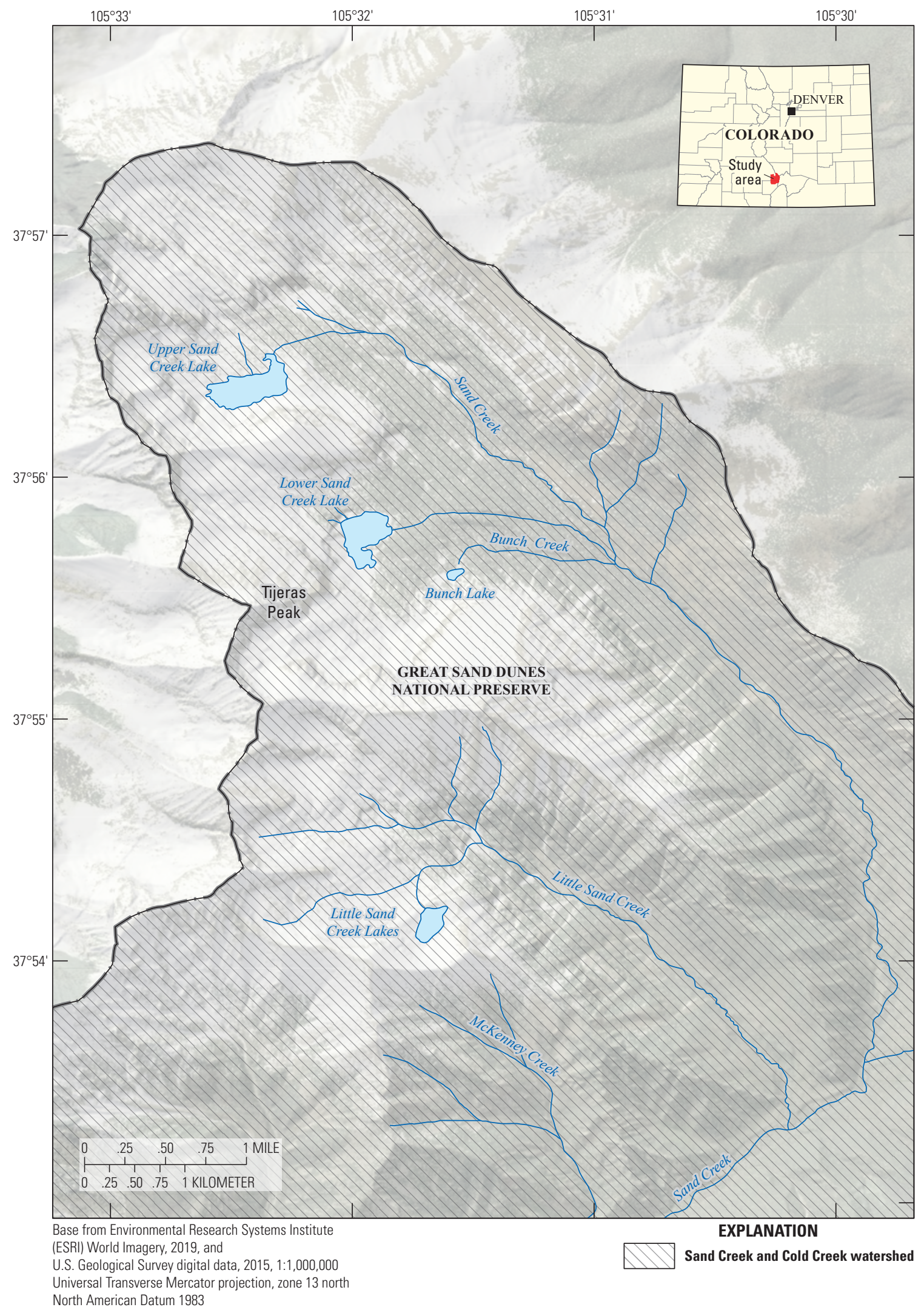

Figure 3. Digitally enhanced imagery of key lake features within the Sand Creek watershed. Lake features in the Sand Creek watershed include Upper Sand Creek Lake, Lower Sand Creek Lake, the larger, easternmost of the Little Sand Creek Lakes (Little Sand Creek Lake), and informally named Bunch Lake. Upper, Lower, and Little Sand Creek Lakes all have populations of hybridized cutthroat trout. Bunch Lake is too shallow for fish but does provide habitat for aquatic macroinvertebrates. The Cold Creek drainage lacks lentic habitat. 
Sand Creek Characterization Study for Cutthroat Trout, Great Sand Dunes National Park and Preserve, Colo.

to orange and golden yellow with hues of olive green dorsally. During spawning, the ventral region of the fish is often bright red and orange, leading to one common name; the red-bellied trout (Behnke, 2002).

\section{Current Rio Grande Cutthroat Trout Management Across its Historical Range}

Currently, RGCT populations represent approximately 12 percent of the historical distribution (Alves and others, 2008). Many factors have contributed to the decline of the RGCT including small population sizes, hybridization with non-native salmonids, competition with non-native salmonids, loss of habitat resulting from wildfire, stream drying, disease, increased water temperatures, poor land management, and angling (Pritchard and Cowley, 2006; U.S. Fish and Wildlife Service [USFWS], 2014a).

RGCT populations have been managed in both New Mexico and Colorado for decades, and conservation of the subspecies is a high priority for both states. New Mexico started investigating the apparent decline in the 1960s, and Colorado listed the RGCT as a State Threatened Species in 1973. Following 11 years of conservation actions by Colorado, the species was delisted in 1984 to a Species of Special Concern, a designation that exists to this day (USFWS, 2014c). In 1998, the RGCT was petitioned for listing under the Endangered Species Act (ESA) of 1973 (16 U.S.C. §1531 et seq. [1973]). That petition was determined by the USFWS to not present substantial information indicating that listing was warranted, a decision which resulted in a subsequent lawsuit against the USFWS. In 2001, the parties reached a settlement, stipulating that the USFWS would initiate a status review for the RGCT and make a determination no later than June 2002. On June 11, 2002, the USFWS published in the Federal Register a determination that listing was not warranted (USFWS, 2002).

In 2003, a lawsuit was filed against the USFWS over the 2002 decision. This lawsuit resulted in a district court ruling that the USFWS's "listing not warranted" finding was not arbitrary or capricious but required a more detailed explanation via a briefing report of their analysis of "significant portion of the range." Following the submittal of that briefing late in 2005, the court ruled in favor of the USFWS. The plaintiffs appealed the court ruling, and that appeal was pending when in 2007, the Solicitor of the Department of the Interior issued a formal legal opinion pertaining to the "the meaning of 'In Danger of Extinction' throughout all or a Significant Portion of Its Range" (U.S. Department of the Interior, 2007). This legal opinion led to the initiation of a new status review for the RGCT.

On May 14, 2008, the USFWS found that RGCT warranted listing as an endangered or threatened species due to population fragmentation and isolation, small population size, non-native trout, drought, and fire. This finding placed the RGCT on the candidate species list, but the USFWS determined that there were other higher priority species that precluded the need to develop a proposed rule to list the RGCT (Moore and others, 2008). As part of another settlement, the USFWS was required to publish a listing decision in the Federal Register by September 30, 2014. The USFWS's decision that listing for RGCT was not warranted was published in the Federal Register on Oct. 1, 2014 (USFWS, 2014b).

A key factor to the USFWS's recent decision that listing the RGCT is not warranted was due to the specific conservation actions and timeline identified in the Rio Grande Cutthroat Trout Conservation Strategy of 2013 (Rio Grande Cutthroat Trout [RGCT] Conservation Team, 2013) through its "Policy for Evaluation of Conservation Efforts When Making Listing Decisions" (USFWS, 2003). This conservation strategy, combined with the Conservation Agreement for Rio Grande Cutthroat Trout in the States of Colorado and New Mexico, identify both the team of signatory management agencies and the conservation actions that are needed for sufficient resiliency, representation, and redundancy to provide for the long-term viability of the subspecies (USFWS, 2014c). For example, Objective 3 (out of 7 total in the conservation strategy) is to restore populations, which is further defined in Objective 3.2 to "Establish New Highly Resilient Secure Conservation Populations." This objective is the driving force behind the evaluation of the Sand Creek watershed for its RGCT reclamation potential.

\section{Rio Grande Cutthroat Trout Biology and Habitat Requirements}

The RGCT lives in high elevation, cold-water streams in New Mexico and Colorado. The RGCT life history is similar to other cutthroat subspecies, which includes spawning in the spring, typically on the descending limb of the hydrograph following snowmelt runoff. Specific timing of spawning is believed to be the result of several factors including length of day, water temperatures, and magnitude and timing of runoff (Sublette and others, 1990). Female RGCT construct redds in gravel substrate and deposit between 200 and 4,500 eggs, which are then fertilized by males (Cowley, 1993). Incubation time is temperature dependent and eggs hatch within 3-7 weeks (Pritchard and Cowley, 2006). The hatchlings (or "alevin") then remain in the gravel for several weeks until the yolk sac is absorbed (Pritchard and Cowley, 2006). Individual RGCT reach sexual maturity at approximately age 3 (McIntyre and Rieman, 1995); however, only individuals over 120 millimeters $(\mathrm{mm})$ in length are considered adults (Pritchard and Cowley, 2006). Aquatic and terrestrial invertebrates make up the bulk of the diet for both juvenile and adult life stages of the RGCT, although some piscivory is evident in larger fish. The expected lifespan of individuals is between $5-8$ years (Benhke, 2002).

In general, the resource needs of RGCT include cold $\left(6-17^{\circ} \mathrm{C}\right)$, oxygen-rich (greater than $[>] 7$ milligrams per liter $(\mathrm{mg} / \mathrm{L})$ at less than or equal to $[\leq] 15^{\circ} \mathrm{C}$ and $9 \mathrm{mg} / \mathrm{L}$ at greater 
than or equal to $[\geq] 15^{\circ} \mathrm{C}$ ), flowing water (velocities between $0.11-0.90$ meters per second $[\mathrm{m} / \mathrm{s}]$ ) with suitable habitat including clean gravel (6-40 $\mathrm{mm}$ substrate diameter) for spawning, instream cover and stream margin habitat, backwaters and side channels for fry, and deep pools ( $>30$ centimeter [cm]) for juveniles and adults (Pritchard and Cowley, 2006; Budy and others, 2012; Zeigler, 2013). Additionally, all life stages require forage including aquatic and terrestrial invertebrates and small fish in some cases (Cowley and Pritchard, 2003; Young and others, 2005; Pritchard and Cowley, 2006).

\section{Threats to Rio Grande Cutthroat Trout Persistence}

The anticipated effects of climate change on the RGCT subspecies have yet to be clearly investigated in detail. However, given the projected increases in air temperature in the southwestern United States and the projected change in the frequency and intensity of stochastic events such as drought, wildfire, and flooding, it is reasonable to expect significant effects to individual populations of RGCT (Zeigler and others, 2013). One recent investigation has indicated that since 1963, there have already been increases observed in air temperature, changes in hydrology, and decreases in snowpack throughout the subspecies' range (Zeigler and others, 2013). A recent wildfire risk assessment concluded that 86 percent of the existing RGCT populations are at extreme or high risk of catastrophic fires and debris flow events (The Nature Conservancy [TNC], 2013). Drought associated with a changing climate is also a concern for managers, given that the most comprehensive baseflow discharge study specific to the range of RGCT found that over 70 percent of the sampled stream segments containing RGCT conservation populations had baseflows of less than 1.0 cubic foot per second $\left(\mathrm{ft}^{3} / \mathrm{s}\right)$ (Zeigler and others, 2013). The RGCT conservation strategy outlines four major effects expected to occur to RGCT populations with climate change, including increased water temperatures, decreased streamflow, seasonal changes in water distribution, and an increased occurrence of extreme events (RGCT Conservation Team, 2013).

\section{A Brief History of Sand Creek Property Ownership and Fisheries Management}

Prior to acquisition by the National Park Service (NPS), the uppermost reaches of Sand Creek, now in the Great Sand Dunes National Park and Preserve, were managed by the U.S. Forest Service (USFS). A portion of the lower watershed was under private ownership with various small mining operations near Sand Creek associated with the mine camp/towns of Duncan and Liberty, Colorado. Following cessation of mining in the latter half of the 20th century, the private property was utilized by hunters and anglers, leading to the development of several off-channel ponds for stocked sport fishing.
Fish stocking in Sand Creek has been ongoing for a significant period of time. It is not certain when non-native Salvelinus fontinalis (brook trout, BRK) were introduced into the lower watershed; however, given a burgeoning fisheries industry in the Rio Grande Basin starting in the late 1800s, it is reasonable to assume that miners may have introduced brook trout as early as 1900 . The upper watershed was protected from invasion of brook trout by many natural waterfalls which serve as possible barriers to upstream migration. However, stocking of non-native cutthroat trout hybrids within the upper watershed began in the 1970s and possibly earlier, compromising native RGCT genetics and eliminating the conservation potential of any Sand Creek headwater populations. Detailed stocking records for Sand Creek began in 1974, when the Colorado Division of Wildlife (CDOW) began stocking a hybrid strain (Yellowstone X Colorado River) of cutthroat trout known as the "Pikes Peak Native." This strain was stocked into the three lakes (Upper Sand Creek Lake, Lower Sand Creek Lake, and the easternmost of the Little Sand Creek Lakes [herein referred to as Little Sand Creek Lake]) every year or every other year up until 1998, when CDOW starting stocking pure RGCT from a local brood known as Haypress. Today, RGCT stocking occurs via plane transplant every year or every other year (Bramblett and Zale, 2002).

Currently, the Preserve portion of Great Sand Dunes National Park and Preserve (GRSA), including the entire Sand Creek watershed, is open to recreational hunting and fishing (fig. 1). Sand Creek is a popular recreation area for backpackers, climbers, anglers, hunters, equestrians, and others. Overall, visitation at GRSA has seen an upward trend for the last 10 years, with 2017 hitting a record 486,935 visitors through the main park entrance (Sharyl Cyphers, NPS, written commun., May 2019).

\section{Great Sand Dunes National Park and Preserve Sand Creek Restoration Planning}

The NPS, and specifically GRSA, was early to initiate conservation actions on behalf of native fish. In 1985, while still a National Monument, GRSA and the Colorado Division of Wildlife (now Colorado Parks and Wildlife [CPW]) carried out a chemical reclamation of Medano Creek to restore RGCT to the watershed. A signatory partner to the first RGCT conservation agreement in 2003, leaders at the GRSA have continued to explore opportunities to restore RGCT in waters under their management. In 2000, Congress passed the Great Sand Dunes National Park and Preserve Act, which converted the Monument into a National Park and expanded the Preserve significantly. The Sand Creek watershed was included in the Preserve expansion, and shortly after acquisition, the NPS began researching the potential for restoring RGCT to Sand Creek, including its tributary streams and lakes, following NPS management policy.

NPS (2006, p. 45) management policy for the restoration of native plants and animals states the following: 
The Service will strive to restore extirpated native plant and animal species to parks whenever all of the following criteria are met:

- Adequate habitat to support the species either exists or can reasonably be restored in the park and if necessary also on adjacent public lands and waters; once a natural population level is achieved, the population can be self-perpetuating.

- The species does not, based on an effective management plan, pose a serious threat to the safety of people in parks, park resources, or persons or property within or outside park boundaries.

- The genetic type used in restoration most nearly approximates the extirpated genetic type.

- The species disappeared or was substantially diminished as a direct or indirect result of human induced change to the species population or to the ecosystem.

- Potential impacts upon park management and use have been carefully considered.

NPS (2006, p. 45) management policy for the management of threatened or endangered plants or animals states the following:

The Service will survey for, protect, and strive to recover all species native to national park system units that are listed under the Endangered Species Act. The Service will fully meet its obligations under the NPS Organic Act and the Endangered Species Act to both proactively conserve listed species and prevent detrimental effects on these species. To meet these obligations, the Service will

- Cooperate with both the U.S. Fish and Wildlife Service and NOAA Fisheries to ensure that NPS actions comply with both the written requirements and the spirit of the Endangered Species Act. This cooperation should include the full range of activities associated with the Endangered Species Act, including consultation, conferencing, informal discussions, and securing all necessary scientific and/or recovery permits;

- Undertake active management programs to inventory, monitor, restore, and maintain listed species' habitats; control detrimental non-native species; manage detrimental visitor access; and reestablish extirpated populations as necessary to maintain the species and the habitats upon which they depend;

- Manage designated critical habitat, essential habitat, and recovery areas to maintain and enhance their value for the recovery of threatened and endangered species;

- Cooperate with other agencies to ensure that the delineation of critical habitat, essential habitat, and/or recovery areas on park-managed lands provides needed conservation benefits to the total recovery efforts being conducted by all the participating agencies;

- Participate in the recovery planning process, including the provision of members on recovery teams and recovery implementation teams where appropriate;

- Cooperate with other agencies, states, and private entities to promote candidate conservation agreements aimed at precluding the need to list species; and

- Conduct actions and allocate funding to address endangered, threatened, proposed, and candidate species.

Natural resource managers at GRSA have implemented multiple management actions over the past decade and dedicated substantial financial resources to RGCT projects. Additionally, as noted above, the NPS has been an active partner and founding signatory to the "Conservation Agreement for Rio Grande Cutthroat Trout within the States of Colorado and New Mexico" (RGCT Conservation Team, 2013).

The primary purpose of this report is to compile and organize information resulting from and related to diverse management work carried out in preparation for the ultimate effort to restore native fish to the Sand Creek watershed.

\section{Methods}

\section{Lake Bathymetry}

Bathymetric profiles were completed for two lakes within the upper Sand Creek drainage (Upper and Lower Sand Creek Lakes) to characterize the physical geometry of each lake and to estimate the total lake volume required for future piscicide treatment/fish removal efforts. A third lake in the basin (Little Sand Creek Lake) was excluded from this bathymetric analysis, as the resident fish are believed to be biologically isolated from downstream reaches of Little Sand Creek due to its perched location within its watershed (see below).

To conduct bathymetric profiles in the two lakes, a Humminbird Model 597ci HD depth finder (Johnson Outdoors, https://www.humminbird.com/) was utilized with its transducer deployed off the bow of a packable pontoon boat. The transducer face was set $20 \mathrm{~cm}$ below the water surface, so all depth readings were adjusted by $+0.2 \mathrm{~m}$. Surface elevation measured during the survey was recorded using prominent landmarks so that volumes could be estimated using surface elevation. Depths were acquired every few seconds while using fins to propel the boat around the lakes at a velocity of approximately 0.8 kilometers per hour $(\mathrm{km} / \mathrm{h})$. Lake perimeters were established by walking the Humminbird unit (without the transducer attached) around each shoreline with the sonar feature disabled and depth values defaulting to $0 \mathrm{~m}$.

All transect data were saved to secure digital (SD) flash media and imported to HumminbirdPC, the supporting data management software for Hummingbird units. Transect 
locations were visualized in GoogleEarth to aid in culling erroneous data. Individual transects were copied from HumminbirdPC and pasted into Microsoft Excel where false depths (first record or shallow water) were eliminated. Coordinates for individual readings were converted from the format recorded in the Humminbird unit (decimal minutes) to Universal Transverse Mercator (UTM) coordinates, and then pasted into the depth and perimeter spreadsheets for each lake. Individual depth readings for each lake were converted to raster maps with $5-\mathrm{m}$ grid cells using additional custom code that calculates the average depth recorded in each cell. Global positioning system (GPS) error was listed as $0.6 \mathrm{~m}$ throughout the surveys. Additional technical details about this methodology and effort are contained in Rogers (2015).

\section{Lake Water Temperature}

The thermal properties of Upper and Lower Sand Creek Lakes were characterized during the 2015 field season. Deep lakes in temperate, northern latitudes are known to stratify during the summer, with an upper stratum of warm and circulating water (epilimnion) separated from a colder, bottom stratum (hypolimnion) by an intervening stratum characterized by a steeply decreasing thermal gradient (metalimnion). Lake stratification dynamics have important implications for interannual viability of resident lentic fish as well as in the logistics of effective and efficient lake treatment using piscicides (NPS, 2008; Finlayson and others, 2010).

A custom vertical stringer of water temperature loggers was constructed for each lake using Onset Hobo Pro v2 data loggers (Onset Computer Corporation, https://www.onsetcomp.com/), closed cell high visibility orange floats, $3 / 8$ in. twisted polypropylene rope, and anchors. In the laboratory, temperature loggers were calibrated and launched to record water temperature 2 times per hour and were affixed along the polypropylene rope at 1-m intervals from the surface float using heavy-duty zip ties.

In the field, the deepest region of each lake was located using frequent depth measurements obtained with a Vexilar LPS-1 portable sounding device (Vexilar Inc., http://vexilar. $\mathrm{com} /$ ) while paddling the lake in a pack raft (Alpacka Raft, https://www.alpackaraft.com/rafting/). These coordinates of the deepest point in each lake were marked with a handheld Garmin GPS unit (Garmin International, https://www.garmin. com/en-US/). On shore, water temperature logger stringers were trimmed to match each lake's maximum depth, and an anchor was constructed and affixed to the bottom of the string using local rocks secured within a heavy-duty protective netting bag.

Water temperature logger stringers were deployed in the deepest region of each lake and left to record water temperatures: Upper Sand Creek Lake from July 2, 2015, to October 14, 2015, and Lower Sand Creek Lake from June 24, 2015, to October 14, 2015. On recovery in October 2015, all lake water temperature loggers were removed from their stringers and were transported to the laboratory where they were downloaded and the data error-checked.

\section{Stream Water Temperature and Intermittency}

In order to characterize thermal and stream permanence conditions throughout the Sand Creek watershed, a multi-step process was used for site selection. Initially, the USGS National Hydrography Dataset (NHD) + geographic information system (GIS) layer of streams was utilized to identify the locations of the mouths of all potential tributaries (ephemeral, intermittent, and perennial) within the Sand Creek watershed (USGS, 2014). These coordinates were input into a handheld Garmin GPS unit, and each of these locations was visited during peak runoff conditions (June 2014). During this initial field visit, if a given stream was unable to be located or was located but was completely dry, it was removed from the list of potential intermittent or perennial streams for further consideration. If a stream was found to be flowing during this 2014 runoff period, it was instrumented with a water temperature logger.

Additional sites were added to further characterize where warming or cooling is occurring spatially. For example, while the creeks draining all three sub-basins with lakes (Upper Sand Creek Lake, Lower Sand Creek Lake, and Little Sand Creek Lake) were sampled at their mouth beginning in June 2014, upstream sites within these lake sub-basins were added in 2015 and 2016 to better understand the role of each lake in shaping the thermal dynamics of the Sand Creek watershed. In 2015, when attempting to recover the stream temperature logger at the mouth of the Lower Sand Creek Lake outlet creek, it was discovered that this logger was actually deployed in the mouth of an additional perennial tributary that did not appear on the NHD+ layer or any other maps. Informally named "Bunch Creek" (to honor long-time Great Sand Dunes National Park and Preserve Natural Resources Manager, Fred Bunch), this logger was retained in the mouth of this creek, and an additional logger was deployed in the outlet of the informally named "Bunch Lake" (at the top of Bunch Creek), and another logger was deployed at the mouth of the Lower Sand Creek Lake outlet creek (fig. 4). A subset of these sites was selected to establish a long-term monitoring network beyond 2016.

All sites were instrumented with stream temperature, intermittency, and conductivity (STIC) data loggers, which are custom-made, low-cost electrical resistance (ER) sensors that facilitate the simultaneous collection of high-resolution water temperature and relative conductivity (RC) data (Chapin and others, 2014). The STIC sensor is a stock HOBO Pendant Temperature/Light data logger (model UA-002-64) that has been modified via the light data channel to yield distinct RC signals when the sensor is wet, dry, or frozen (Chapin and others, 2014). When wet, the STIC sensor records a signal that varies based on site water temperature and conductivity. When the STIC is removed from water, the signal falls to zero, as air between the external electrodes provides negligible resistance. When water around the STIC external electrodes begins to freeze, the $\mathrm{RC}$ signal drops to just above 0 while the water temperature signal drops below 0 . Given these distinct signal variances, data screening for dry and frozen logger periods is significantly less subjective than utilizing temperature 


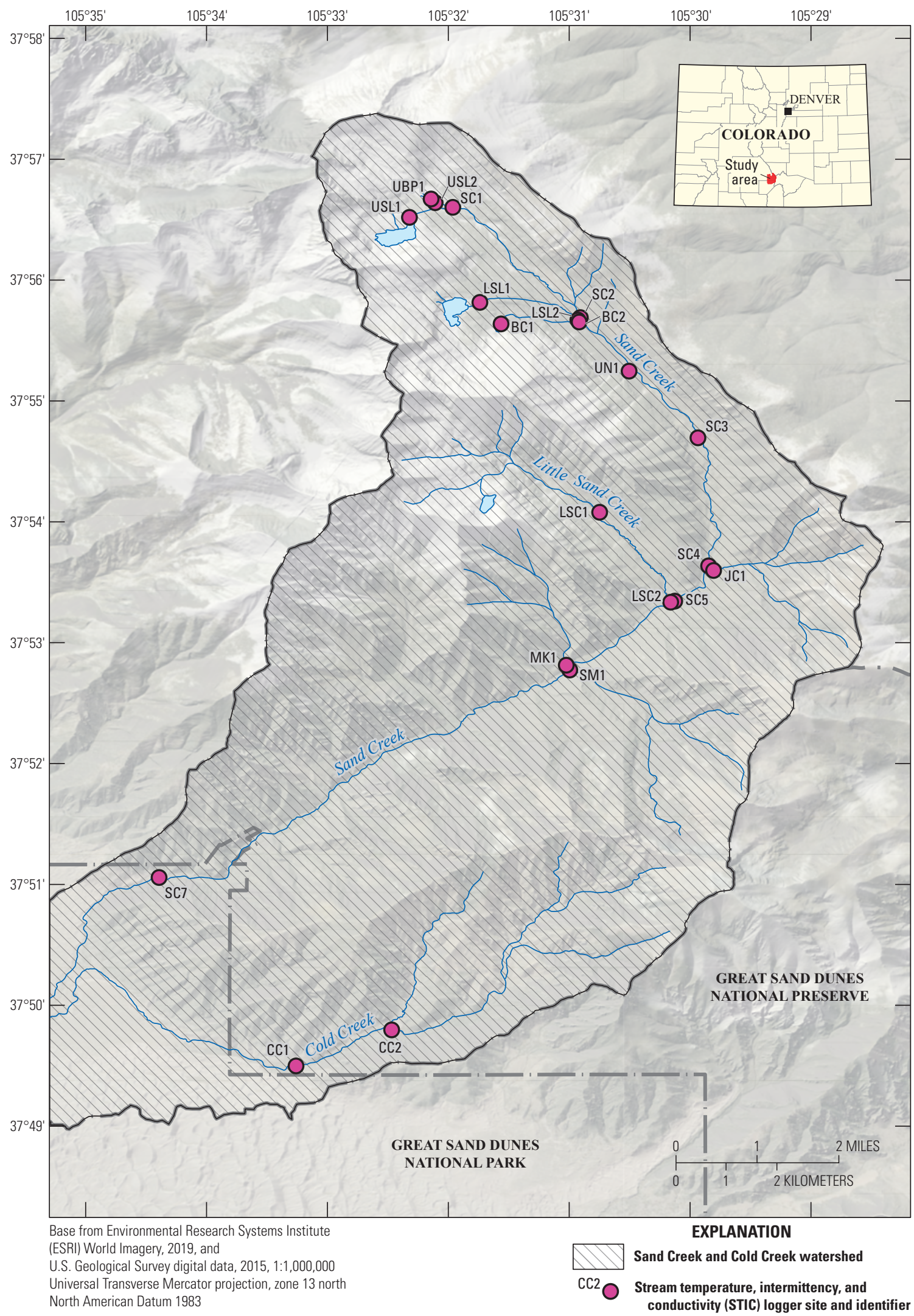

Figure 4. Digitally enhanced imagery of stream temperature, intermittency, and conductivity (STIC) monitoring sites within the Sand Creek, Great Sand Dunes National Park and Preserve, Colorado. Loggers were distributed spatially within the watershed to characterize the thermal regime of mainstem Sand Creek and several other perennial tributaries. Coordinates for these sites can be found in table 1 and a summary of STIC data can be found in table 2 . 
data alone. When properly deployed, these sensors can be effectively used to provide critical information about aquatic habitat availability by differentiating flowing, dry, and frozen conditions within a given stream.

STIC data loggers were deployed in the thalwegs of riffle habitats at sites throughout the Sand Creek watershed to document any potential occurrences of stream intermittency or stream freezing within these streams, to assess the suitability of the existing thermal regime for salmonids, and to assess the thermal conditions relative to the suitability for cutthroat trout, as approximated by the Cold Stream Tier 1 chronic water temperature standards for the State of Colorado (Colorado Department of Public Health and Environment [CDPHE], 2018). STIC loggers were deployed annually within the Sand Creek mainstem and relevant tributaries between 2014 and 2016 (table 1). Figure 4 illustrates the spatial distribution and relationship of STIC logger sites.

All STIC loggers were calibrated in the laboratory at two temperatures $\left(0\right.$ and $\left.25^{\circ} \mathrm{C}\right)$, and the intermittency $\mathrm{RC}$ response tested via sporadic submersion in water to illicit an instantaneous response. The manufacturer specification lists the STIC accuracy at $\pm 0.53{ }^{\circ} \mathrm{C}$ in ranges from 0 to $50^{\circ} \mathrm{C}$. All STICs were tested for functionality and accuracy in the laboratory upon modification. All STICs used in Sand Creek were tested at 20 and $5{ }^{\circ} \mathrm{C}$ and each recorded well within manufacturers parameters. In addition, upon launching a new data record, each device was tested in hand to have accurate temperature and ER readings.

In the field, STIC loggers were launched at a 60 -minute collection interval, secured within a white polyvinyl chloride (PVC) housing, and subsequently anchored to the thalweg of each stream reach using a $3-\mathrm{ft}$ predrilled metal stake driven into the streambed. The housing was placed on the metal stake and secured with a neoprene grommet and a coated copper wire threaded through one of the predrilled holes in the metal stake. Coordinates of the locations for deployments were recorded with a handheld Garmin GPS unit. Coordinates are recorded in North American Datum of 1983 (NAD 83), Universal Transverse Mercator (UTM) zone 13N.

On each recovery visit, STIC loggers were replaced or removed, with data downloaded in the laboratory to the Onset HOBOware software platform via an Onset Optic USB Base Station (Base U-4) (Onset Computer Corporation, https:// www.onsetcomp.com/products/communications/base-u-4). Data were screened for errors and for periods where the logger went dry or was frozen, and then input into summary spreadsheets wherein select biologically relevant thermal metrics were calculated, including the summertime maximum weekly average temperature (MWAT), the summertime daily maximum temperature (DM), and the July and August monthly mean temperatures (table 2).

\section{Stream Discharge}

Stream discharge was measured throughout the mainstem of Sand Creek and in several key perennial tributaries during the fall sampling events of 2014 and 2015. The fall sampling period was selected for flow measurements to help characterize the magnitude and interannual variability of discharge during the time of year when piscicide applications are planned to occur in August 2019. Stream discharge was typically measured in close proximity to STIC logger locations to obtain co-located thermal and hydrological information. A complete list of discharge measurement locations is presented in table 3 and a map of the flow measurement locations is provided in figure 5 .

Discharge was measured by measuring velocity along a measured cross-section area (Harrelson and others, 1994). The following criteria were considered in the selection of crosssections for measuring stream discharge in the Sand Creek watershed:

1. Depths mostly greater than $15 \mathrm{~cm}$

2. Velocities mostly greater than $0.15 \mathrm{~m} / \mathrm{s}$

3. U-Shaped channel free of large boulders, woody debris, or dense aquatic vegetation

4. Flow relatively uniform, with no eddies, backwaters, or excessive turbulence

Once cross-sections were selected, a fiberglass field measuring tape was strung tightly and level across the stream, perpendicular to the flow. Total wetted stream width was measured, and the resultant measurement was divided into approximately 20 equal-sized intervals, with no more than 10 percent of the total measured flow passing through a single cross-sectional unit. At each interval, the distance from water's edge, depth of water, and stream velocity (measured at 0.6 of the measured depth below the surface of the water) were measured and recorded using a Marsh McBirney Flo-Mate 2000 magnetic-head flow meter (Marsh McBirney Inc., Md., https:// www.hach.com $/ \mathrm{mmi}$ ) attached to a Rickly top-set wading rod (Rickly Hydrological Co., https://rickly.com/). In 2015, a failure of the Flo-Mate meter resulted in a switch to measurements with a Rickly Pygmy meter. All measurements were input into a spreadsheet which was used to calculate a total streamflow estimate for each site.

\section{Fish Distribution}

Existing fish community distribution and composition within the Sand Creek watershed were a key component of this study. This baseline establishes the geographic extent and biological constraints factored into future piscicide treatment planning and native trout reintroduction efforts. To inform this study, CPW provided information regarding the agency's stocking history within the watershed, and a 2001 fisheries study was identified that contained baseline fisheries data, including electrofishing survey results from Sand Creek and hook and line sampling efforts form Upper Sand Creek Lake, Lower Sand Creek Lake, and Little Sand Creek Lake (CPW, 2001).

To define the spatial extent of existing fish distribution within the watershed, all perennial tributaries with a direct 
Table 1. Stream temperature, intermittency, and conductivity (STIC) logger site descriptions, abbreviated site names, and geographic locations, Sand Creek watershed, Great Sand Dunes National Park and Preserve, Colorado. STIC sites are displayed in figure 4 .

[Coordinate system, North American Datum (NAD83); Universal Transverse Mercator (UTM) zone 13N]

\begin{tabular}{|c|c|c|c|}
\hline Mainstem & Site ID & UTM $\mathrm{X}$ & UTM Y \\
\hline Sand Creek below Upper Sand Lake/beaver pond confluence & $\mathrm{SC} 1$ & 453194 & 4199672 \\
\hline Sand Creek above Lower Sand Lake outlet creek confluence & $\mathrm{SC} 2$ & 454731 & 4197974 \\
\hline Sand Creek below mainstem beaver pond complex & $\mathrm{SC} 3$ & 456148 & 4196125 \\
\hline Sand Creek above Jones Creek confluence & $\mathrm{SC} 4$ & 456267 & 4194163 \\
\hline Sand Creek above Little Sand Creek confluence & SC5 & 455853 & 4193625 \\
\hline Sand Creek at bottom & SC7 & 449568 & 4189428 \\
\hline Tributaries & Site ID & UTM X & UTM Y \\
\hline Upper Sand Lake outlet creek-outlet & USL1 & 452667 & 4199521 \\
\hline Upper Sand Lake outlet creek-mouth & USL2 & 452980 & 4199744 \\
\hline Upper Beaver Pond tributary-mouth & UBP1 & 452931 & 4199801 \\
\hline Lower Sand Lake outlet creek-outlet & LSL1 & 453514 & 4198214 \\
\hline Lower Sand Lake outlet creek-mouth & LSL2 & 454701 & 4197937 \\
\hline Bunch Creek-outlet & $\mathrm{BC} 1$ & 453769 & 4197883 \\
\hline Bunch Creek-mouth & $\mathrm{BC} 2$ & 454716 & 4197907 \\
\hline Steep unnamed tributary - mouth & UN1 & 455318 & 4197151 \\
\hline Jones Creek-mouth & $\mathrm{JC} 1$ & 456327 & 4194092 \\
\hline Little Sand Creek-upstream & LSC1 & 454949 & 4194991 \\
\hline Little Sand Creek — mouth & LSC2 & 455804 & 4193609 \\
\hline Smith Creek-mouth & SM1 & 454573 & 4192577 \\
\hline McKenney Creek — mouth & MK1 & 454531 & 4192651 \\
\hline Cold Creek-lower site & $\mathrm{CC} 1$ & 451214 & 4186532 \\
\hline Cold Creek-upper site & $\mathrm{CC} 2$ & 452379 & 4187077 \\
\hline
\end{tabular}


Table 2. Summary of stream temperature metrics from mainstem Sand Creek and tributaries measured in 2014 through 2016, Great Sand Dunes National Park and Preserve, Colorado. A July mean temperature above $7.8^{\circ} \mathrm{C}$ is an important metric for successful recruitment of cutthroat trout (Harig and Fausch, 2002). The stream temperature, intermittency, and conductivity (STIC) logger deployed at site SC2 could not be recovered in 2016 and is labeled as LOST in this table. Locations of temperature metrics can be found in figure 4. Coordinates for Site ID can be found in table 1.

$\left[\mathrm{DM}\right.$, daily maximum temperature; MWAT, maximum weekly average temperature; ${ }^{\circ} \mathrm{C}$, degrees Celsius; - , no data; Blue highlighted values indicate streams where water temperatures are likely too cold for natural recruitment]]

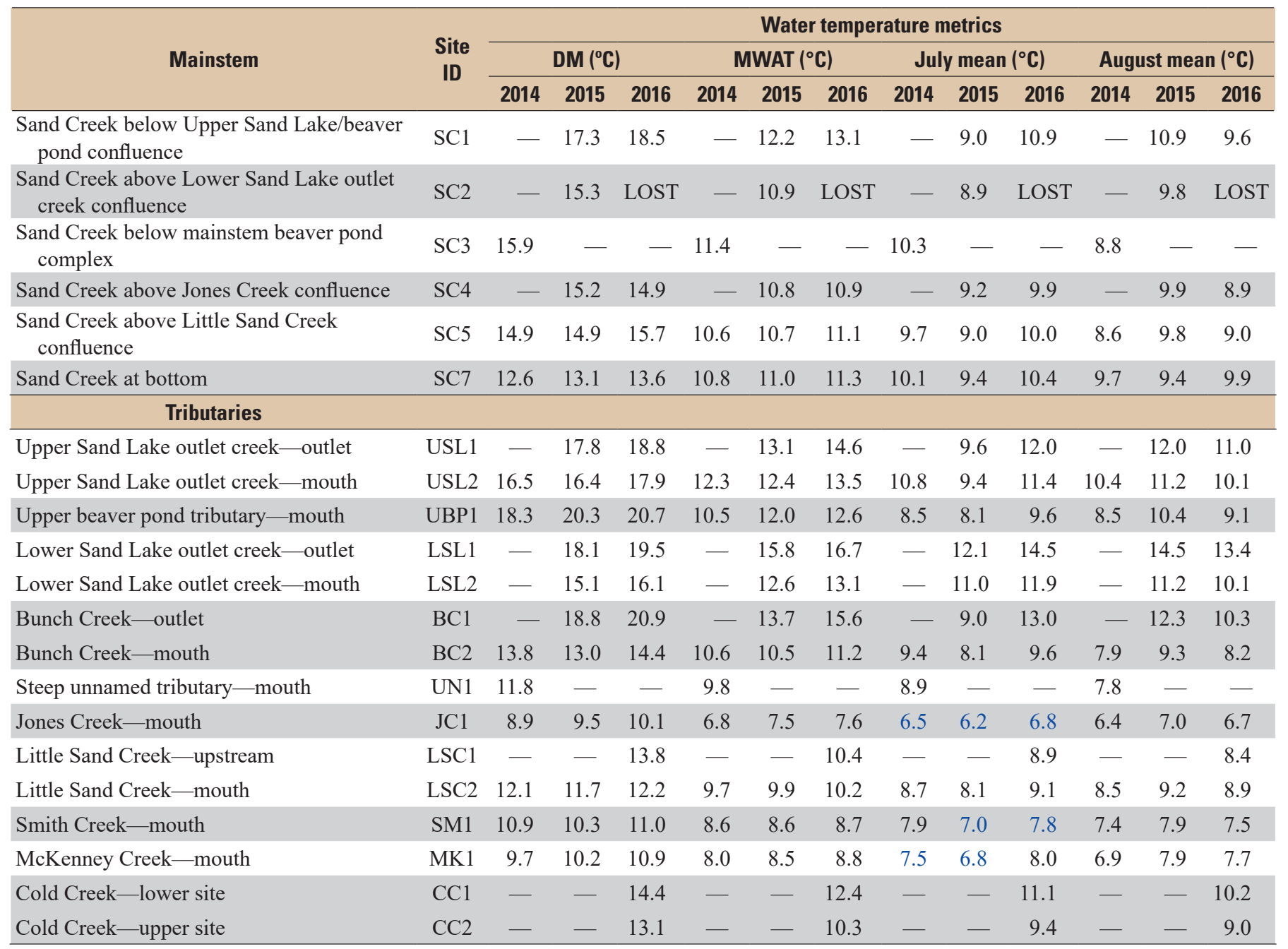


Table 3. A summary for baseflow stream discharge measured in August 2014 and 2015, within the Sand Creek watershed, Great Sand Dunes National Park and Preserve, Colorado. Data collected from stream temperature, intermittency, and conductivity (STIC) loggers indicate that all the monitored sites are perennial. Locations of discharge measurements can be found in figure 5 and coordinates for Site ID can be found in table 1.

[Table cells with "n" abbreviate "not intermittent"; fts/s; cubic feet per second]

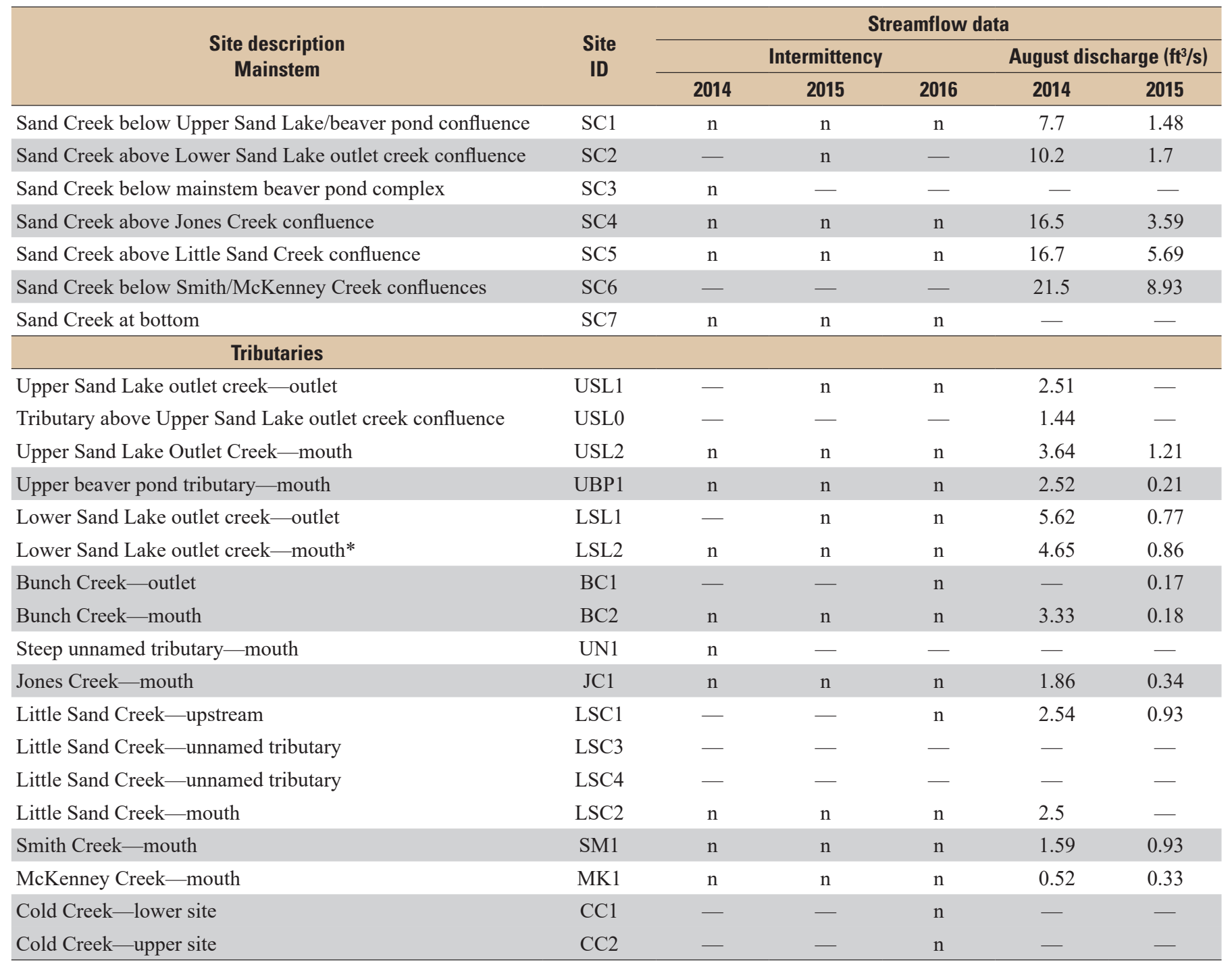

Figure 5. (facing page) Digitally enhanced imagery of the flow measurement sites within the Sand Creek watershed, Great Sand Dunes National Park and Preserve, Colorado. Discharge measurements were recorded during the 2014 and 2015 field seasons to understand available habitat and estimate resources required for treatment. Several perennial tributaries contribute cold water to mainstem Sand Creek as it flows downstream into the sand dunes, which gives Sand Creek a unique thermal signature that gets colder as it descends in elevation. Summary discharge data from these sites can be found in table 3. 


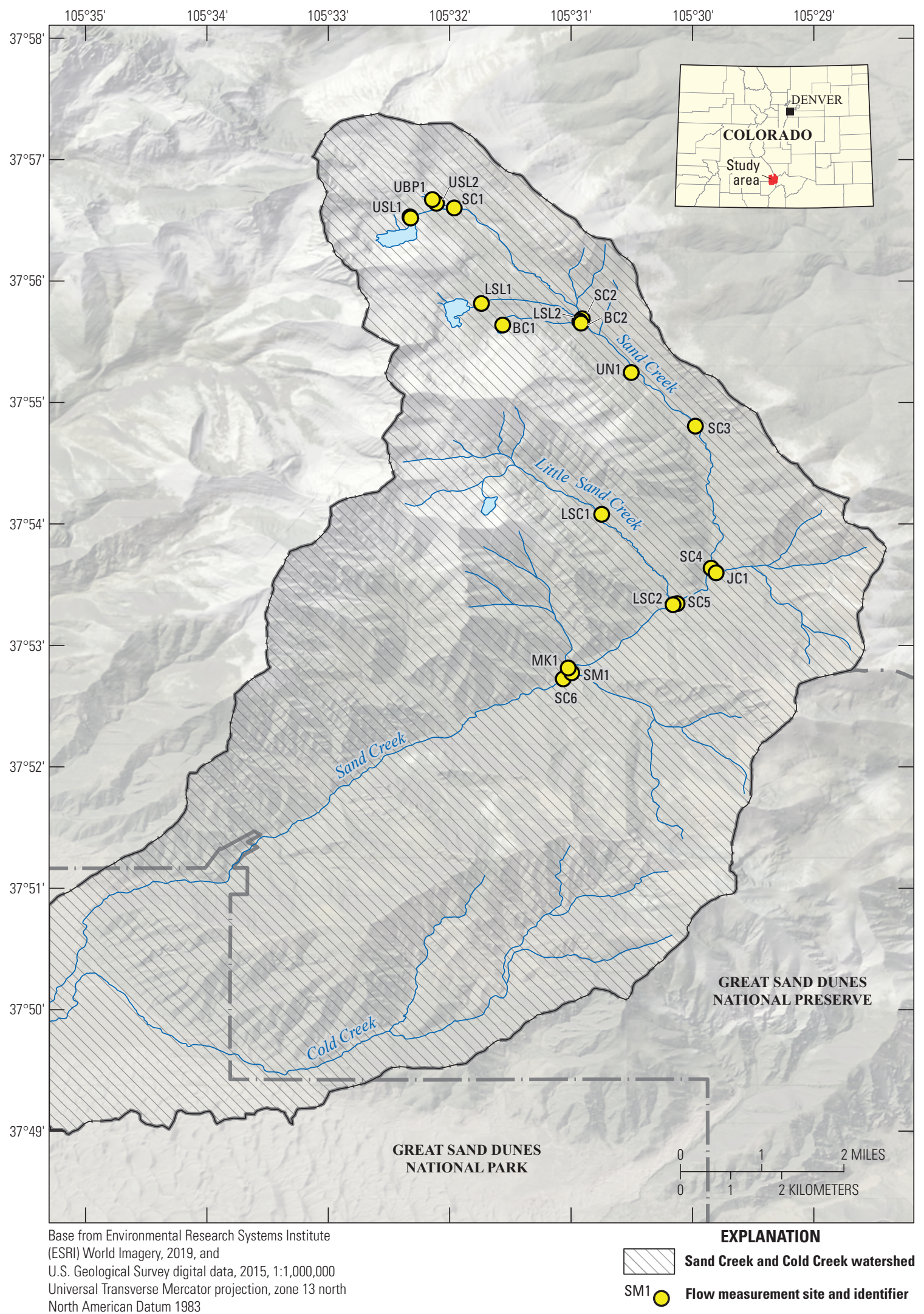


confluence with Sand Creek were surveyed including Cold Creek, which is a perennial tributary with infrequent but documented surface connectivity to Sand Creek.

Fisheries investigations were carried out in both lakes and streams within the Sand Creek watershed. Upper Sand Creek Lake, Lower Sand Creek Lake, Little Sand Creek Lake, and an unnamed kettle lake informally known as Bunch Lake were studied. Perennial stream reaches included the two outlet streams from Upper and Lower Sand Creek Lakes, and the outlet stream from Bunch Lake (informally called Bunch Creek). The mainstem of Sand Creek was divided into distinct reaches that were separated by possible natural migration barriers, and fish survey locations were identified in these reaches. Additional perennial streams that were surveyed for the presence of fish included Jones Creek, Little Sand Creek, McKenney Creek, and Smith Creek.

Fisheries surveys for streams with no documentation of previous fish presence began with visual surveys to establish a suspected presence or absence. Fish were observed in Lower Sand Creek Lake outlet creek, Upper Sand Creek outlet creek, the mouth of Little Sand Creek, and other reaches with prior data. Several lower elevation perennial tributaries in the Sand Creek watershed including Jones Creek, McKenney Creek, and Smith Creek were suspected to be fishless. These initial "fishless" determinations were supported using spatially extensive single-pass electrofishing surveys and the collection and analysis of environmental DNA (e-DNA) samples (see methods below).

Due to very low population densities and resultant difficulties capturing and collecting a statistically robust number of tissue samples $(n=30)$ in Little Sand Creek Lake, a 75-foot experimental gill net was deployed in 2016 in an attempt to improve capture efficiency. A 2-hour gill net set did not result in any additional fish capture. The net was then employed as a seine to capture individual trout that were relatively immobile and easily visible from above. This modified netting technique resulted in the capture of two additional individuals. However, total sample size remained insufficient for a statistically robust genetic analysis. Although sample size was insufficient for a statistically robust genetic analysis, tissue was still run for the genetic makeup of those individuals and compared to the more statistically robust Upper Sand Creek Lake genetics.

\section{Genetics}

To evaluate the current genetic composition of fish populations in the Sand Creek watershed, fin clip samples were collected from fish in both the Upper and Lower Sand Creek Lakes in 2015. Since native RGCT have been exclusively stocked into these lakes for the last two decades, the genetics of fish currently in each lake can test whether natural reproduction is regularly occurring in each lake. If reproduction is not occurring in a given lake, the genetics of that lake's fish population should reflect the genetics of the native RGCT, the fish that has been stocked for the last 20 years, as this period exceeds the expected lifespan of those legacy "Pikes Peak" strain fish. If, however, relatively regular in-lake reproduction is occurring within a given lake, the genetics signature of the population would more likely reflect a combination of the genetics of the fish that were stocked historically (that is, "Pikes Peak" strain cutthroat) and the genetics of the fish that have been stocked more recently (that is, RGCT). As headwater lakes, both Upper and Lower Sand Creek Lakes are hydrologically connected to streams throughout the entire Sand Creek watershed downstream. Understanding the cutthroat trout genetics in these lakes is expected to reflect the genetics of all cutthroat fisheries below them, making genetic sampling of stream populations unnecessary.

Fish were sampled $(\mathrm{n}=30)$ in Upper and Lower Sand Creek Lakes in 2015 using hook and line methods from a stationary position on the lake's perimeter. Fish were captured by multiple field personnel, the caudal fin was secured using sterilized locking forceps, and a small caudal fin tissue sample $(<10 \mathrm{~mm})$ was clipped from the fish using small, sterilized surgical scissors. The caudal fin clip sample was then placed in an individually labeled Falcon tube filled with an 80-percent ethanol solution to preserve the genetic material. Sampling equipment (forceps and scissors) were decontaminated between samples by dipping in a 20-percent bleach solution, and contact surfaces were further sterilized over open gas flame for several seconds. Each captured fish was inspected to ensure individuals were not sampled more than once, and then photographed for phenotypic comparisons with genetic results.

Fin clip samples were sent to Pisces Molecular (http:// www.pisces-molecular.com/) for admixture analysis. DNA extracted from the fin clip sample material was analyzed for genetic signature using STRUCTURE 2.2 to determine similarity or dissimilarity between test samples and known genetic references. A detailed description of laboratory methods is attached as appendix 1 "Summary of Cutthroat Trout Amplified Fragment Length Polymorphism (AFLP) Analysis Procedure and Results."

\section{Environmental DNA}

Environmental DNA (eDNA) samples were collected as a supplementary line of evidence to determine the presence or absence of fish within tributaries of mainstem Sand Creek (fig. 6). Accurate documentation of the presence or absence of fish within specific Sand Creek tributaries informs limiting the spatial scope of future piscicide treatments (that is, fishless tributaries would not need to be treated and greatly reduce cost and effort needed).

Environmental DNA samples were collected using a modified 1-liter (L) Nalgene bottle fitted with a Swinnex 0.10 micrometer $(\mu \mathrm{m})$ filter, pretreated with carrier DNA at Pisces Molecular Laboratory. Preventative measures were taken to ensure that upstream water was not contaminated with electrofishing equipment before and (or) during the eDNA sampling effort. At each site, modified Nalgene bottles were filled with site water, and a compact bike/air pump was used to compress air through the modified Nalgene cap to force site water 
through the Swinnex filter. A minimum of $4 \mathrm{~L}$ was filtered from each site, and immediately after filtration, the Swinnex filter was injected with 5 milliliters $(\mathrm{mL})$ of 80 -percent ethanol solution to preserve DNA and carrier material.

Filters were individually double bagged and labeled consistent with laboratory tracking standards. Filters were stored in an improvised light-tight cooler for no longer than 96 hours before delivery to Pisces Molecular for immediate preservation and laboratory analysis. A positive control sample was taken in a pool containing hybrid cutthroat trout (eDNA POS Control) in addition to two sample blanks and two duplicates for quality assurance/quality control (QA/QC) purposes.

\section{Benthic Invertebrates}

Benthic macroinvertebrate (BMI) communities of mainstem Sand Creek and the outlet creeks of both Upper and Lower Sand Creek Lakes were previously studied across several sites from 2005-2007 (Zuellig and others, 2006). This research provides background data on abundance and diversity for most of mainstem Sand Creek; however, many of these previously sampled sites fell within the identified treatment zone (that is, stream reaches with non-native fish), and previous sampling had not occurred for perennial tributary reaches in non-treatment zones (that is, Bunch Creek, Jones Creek, McKenney Creek, and Smith Creek). In 2015, BMI sample sites were selected in non-treatment zones to determine their ability to recolonize the treatment zone (that is, mainstem Sand Creek) if the piscicide collaterally affects the invertebrate communities (fig. 7).

These selected sites were sampled by Colorado Department of Public Health and Environment (CDPHE) field personnel in September 2015 following standard operating procedures for hard-bottom streams, and samples were identified and enumerated in the laboratory (CDPHE, 2017). To quantify these data, CDPHE used a bioassessment tool known as the macroinvertebrate multi-metric index (MMI). This tool generates a score that ranges from $0-100$ based on weighted metric categories such as taxa richness, composition, sensitivity or pollution tolerances, functional feeding groups, and so forth. Because the tool is designed to respond to a wide range of water quality stressors, monitoring of MMI scores allows CDPHE to designate thresholds for high scoring water, attainment, or impairment (CDPHE, 2017). The Sand Creek watershed is biologically categorized as Biotype 2 (mountains) with aquatic life thresholds for impairment (MMI 42), attainment (MMI 50), and high scoring water (MMI >64) (CDPHE, 2017).

Figure 6. (following page 18) Digitally enhanced imagery of environmental deoxyribonucleic acid (eDNA) sampling sites within the Sand Creek watershed, Great Sand Dunes National Park and Preserve, Colorado. Environmental DNA (eDNA) samples were taken in support of electrofishing surveys to determine the presence or absence of fish. Data supporting the presence and absence of fish within the watershed have helped define and greatly reduce the treatment zone and therefore reduce the resources required for reclamation. Samples were analyzed based on the most adjacent species of fish (for example, analyzed for Salvelinus fontinalis [brook trout, BRK], hybrid cutthroat trout [General cutthroat trout with known or unknown genetic admixture, CUTT], or in some cases both). An eDNA positive control (POS control) sample was taken in a location with known hybrid cutthroat trout to ensure detection. Other eDNA results were negative (NEG), which supports electrofishing data. Results from eDNA sampling can be found in table 4.

Figure 7. (following page 19) Digitally enhanced imagery of benthic macroinvertebrate (BMI) sampling sites within the Sand Creek watershed, Great Sand Dunes National Park and Preserve, Colorado. Historical BMI sampling (Zuellig and others, 2006) was primarily focused in the upper watershed and mainstem of Sand Creek, with most sample sites falling inside the defined treatment zone. In 2015, Colorado Department of Public Health and Environment (CDPHE) sampled BMI in perennial streams outside of the treatment zone for taxa richness and abundance (MMI score) to identify recolonization sources in the event some of the mainstem Sand Creek BMI community is collaterally affected during treatment. 


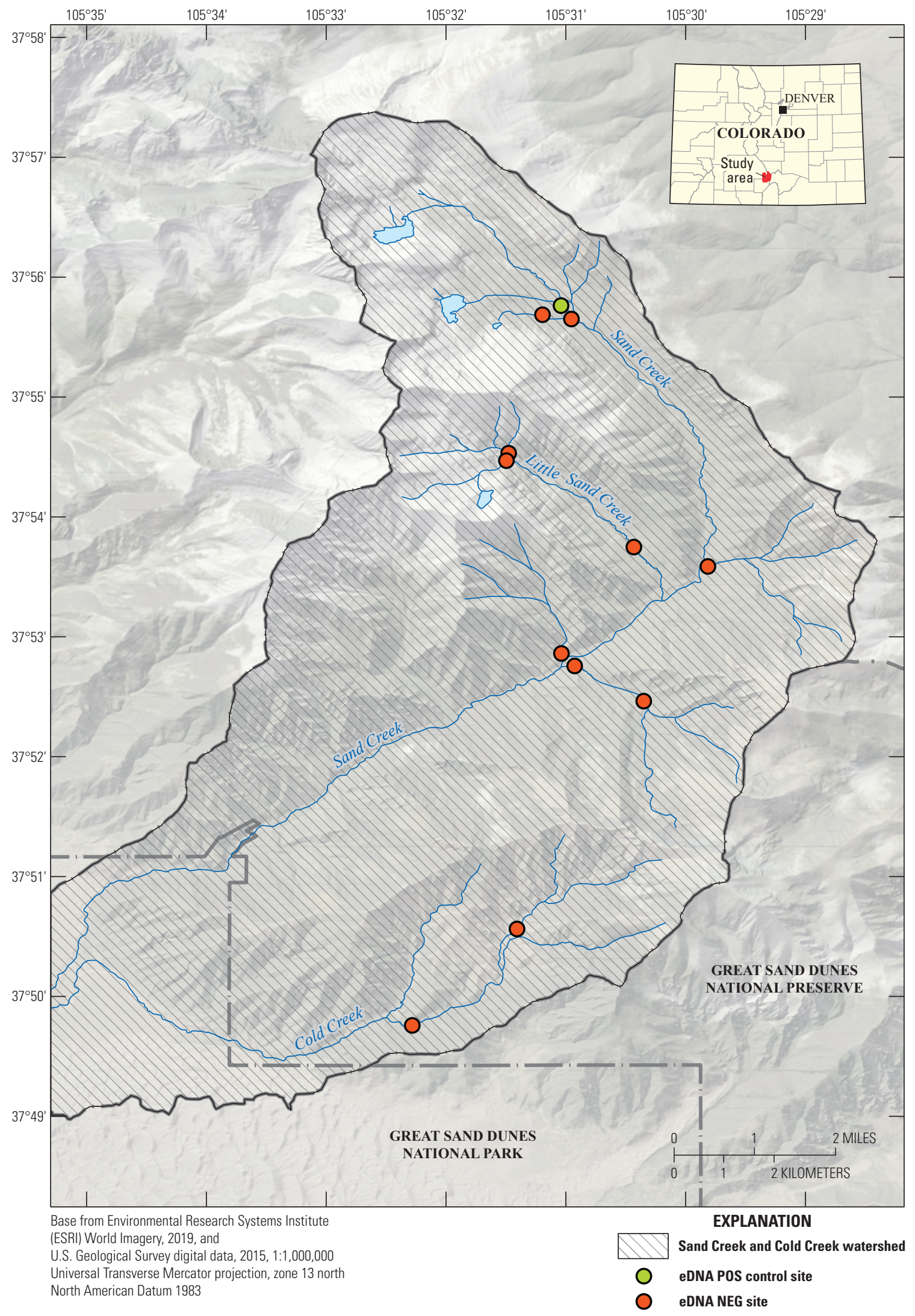




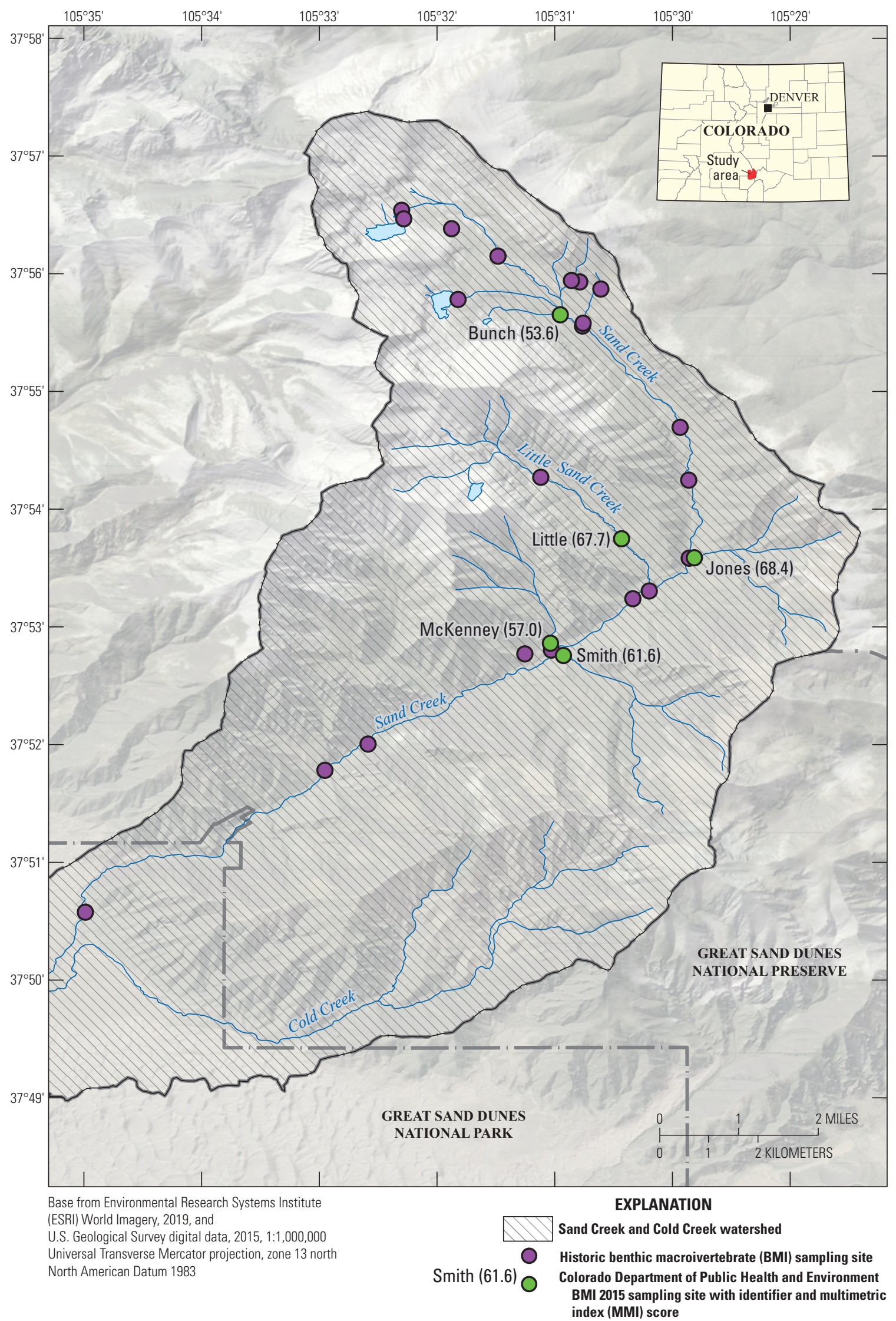




\section{Results and Discussion}

The CPW records indicate that state-sponsored fish stocking began in the watershed in the early 1970s. A hatchery-derived strain of cutthroat trout called the "Pikes Peak Natives" were the primary trout stocked in the watershed through 1998, when management direction changed to stocking solely native Rio Grande cutthroat trout from a local broodstock called "Haypress" (Bramblett and Zale, 2002). Hook and line tactics were employed at Upper Sand Creek Lake, Lower Sand Creek Lake, and Little Sand Creek Lake, all of which were previously stocked, to collect tissue samples to evaluate the genetics of current lentic populations within the watershed. Bunch Lake, which appears shallow, was determined to be fishless through extensive field observation and downstream eDNA sampling and is therefore not included in the following discussion.

\section{Lake Physical and Biological Conditions}

\section{Upper Sand Creek Lake}

\section{Physical Conditions}

Upper Sand Creek Lake is situated at tree line $(11,770 \mathrm{ft})$, with rock scree composing most of the substrate on the shore and within the lake. The lake was measured at approximately 10.6 hectares (ha) in surface area, with a maximum depth of $18 \mathrm{~m}$ and an estimated volume of 450 acre-feet (acre-ft) during the 2015 bathymetric survey (Rogers, 2015) (fig. 8). On the north side of the lake, an assembly of approximately 15 seasonal kettle ponds was identified that appear to be hydrologically disconnected from Upper Sand Creek Lake. Upper Sand Creek Lake has a long ice-over season due to elevation, shading, and high snowpack. During the period of our study, complete ice cover was observed as late as June 30. Two small streams, approximately $100 \mathrm{~m}$ in length, were observed to intermittently flow into Upper Sand Creek Lake from the northwest.

Figure 9 illustrates how water temperature in Upper Sand Creek Lake changed at depth during the summer of 2015, clearly showing the establishment of a thermocline just after ice-off in early July, and the break-up of that thermocline in late September. Understanding the depth, strength, and timing of stratification increases the effectiveness and helps define the treatment zone in this lake. Based on this stratification analysis, it appears that Upper Sand Creek Lake is well stratified from late July to early September, with fall lake turnover projected for early November.

Water in Upper Sand Creek Lake was observed to flow out of the lake in the northeastern corner, where a debris dam possibly established by beaver activity creates the outlet. The outlet stream was observed to have limited fish passage potential for individual fish to return to the lake due to the complexity of the debris dam and a significant vertical drop, especially at lower flows. Moving downstream, the habitat in the outlet stream is steep and confined with at least partial/seasonal possible barriers less than $100 \mathrm{~m}$ downstream. Importantly, a secondary low-gradient channel with suitable and available habitat joins the outlet stream immediately upstream of probable permanent waterfall barriers. This secondary channel would also need to be treated to its source.

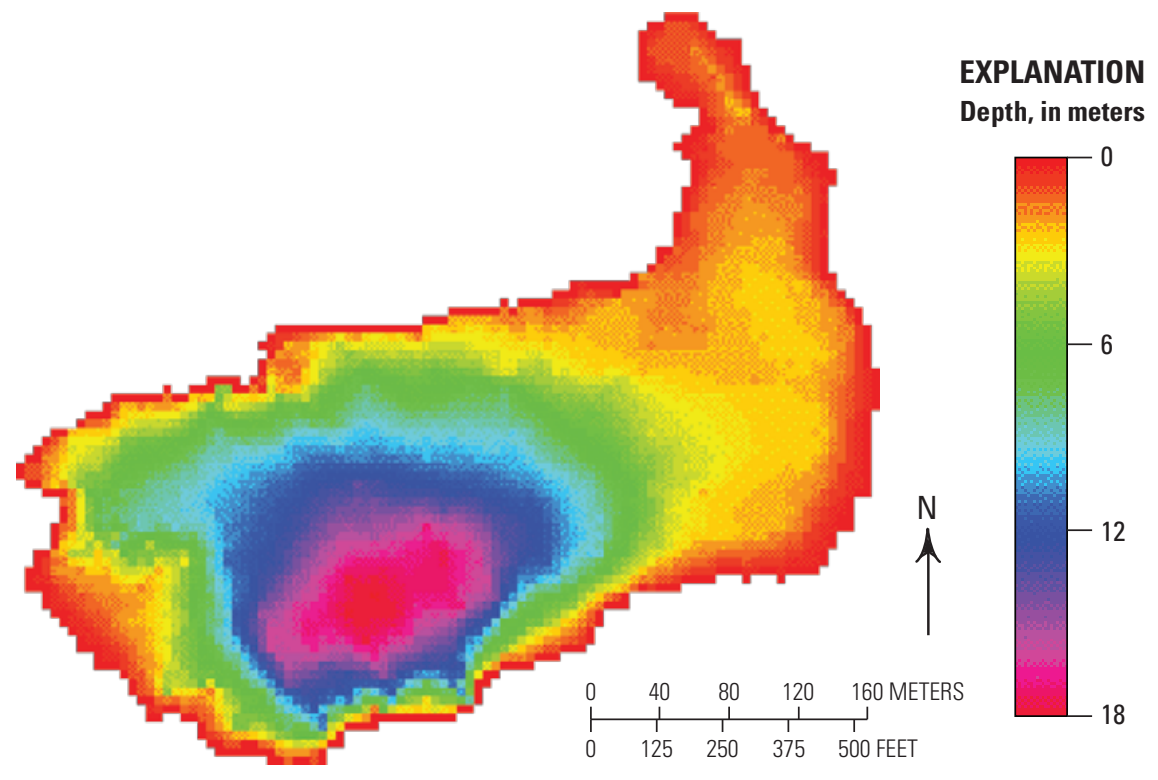

Figure 8. Bathymetric profile of Upper Sand Creek Lake, Great Sand Dunes National Park and Preserve, Colorado (source of image, Rogers, 2015). Bathymetry and seasonal stratification profiles are helpful in preparation for piscicide treatment of lentic environments (Finlayson and others, 2010). 
Upper Sand Creek Lake Thermocline, Summer 2015

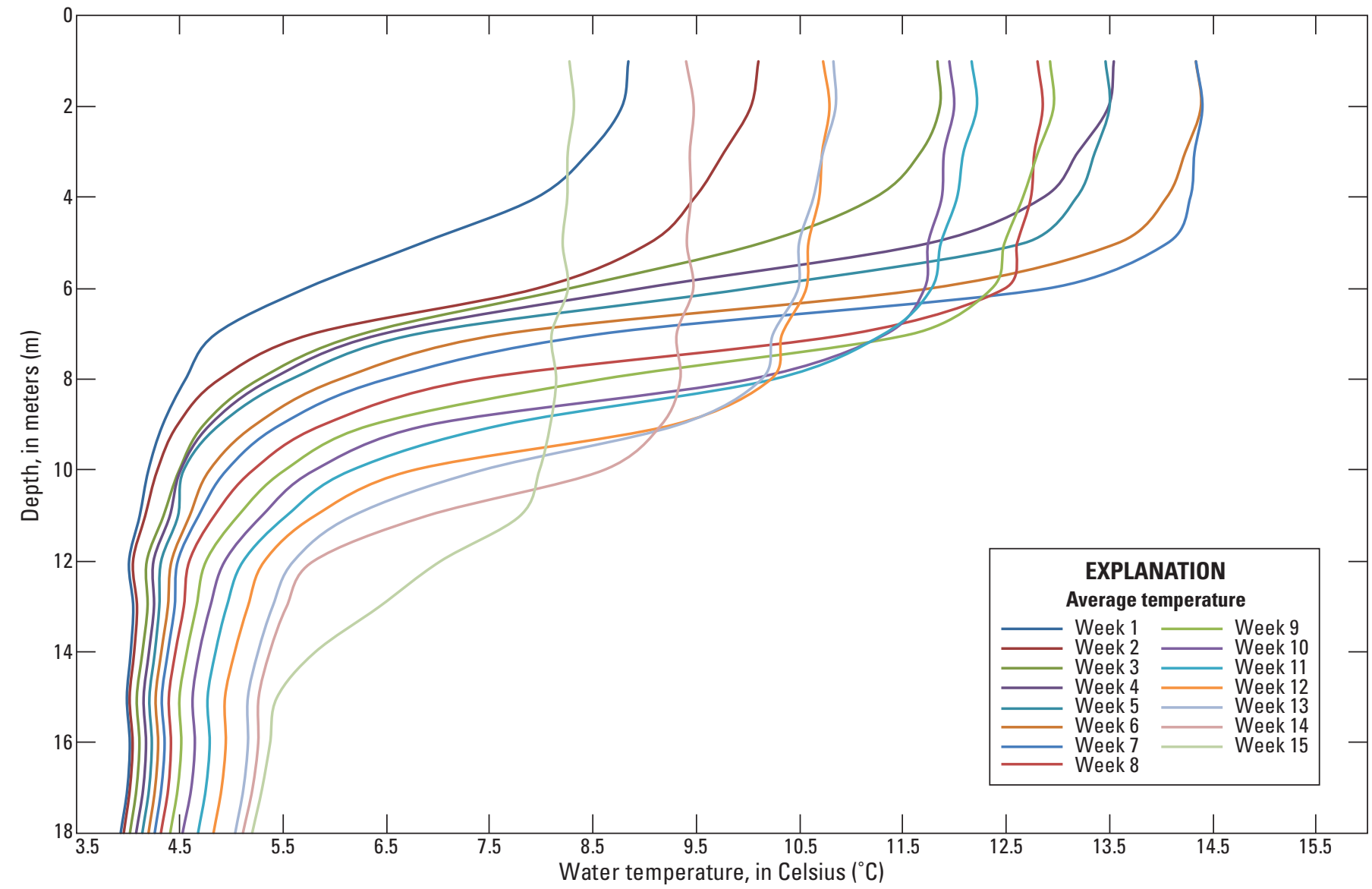

Figure 9. Thermocline graph of Upper Sand Creek Lake, Great Sand Dunes National Park and Preserve, Colorado, shows a strong thermal stratification for most months that the lake is ice free. Based on this stratification analysis, it appears that Upper Sand Creek Lake is well stratified from late July to early September, with fall lake turnover projected for early November. These data are used to identify the total amount of available fish habitat that needs piscicide treatment (Finlayson and others, 2010).

\section{Biological Conditions}

Results from amplified fragment length polymorphism (AFLP) analysis of Upper Sand Creek Lake fin clip samples demonstrate that although the Upper Sand Creek Lake trout population is dominated by RGCT genetic signatures (14 out of 30 fish sampled were pure RGCT), other fish share genetic signatures with Oncorhynchus mykiss (rainbow trout, RBT), YSCT, and CRCT (fig. 10). When compared to CPW's stocking history, this genetic community composition (specifically the carryover of previously introduced "Pikes Peak" cutthroat genetics mixed with the more recently Haypress Lake RGCT genetics) suggest that lentic reproduction is occurring in Upper Sand Creek Lake on an infrequent, but persistent basis. These results suggest that some of the pure RGCT that are being currently stocked as fingerlings are recruiting into the population.

Photographs were used to qualitatively compare the phenotypic characteristics of pure RGCT to admixed cutthroat trout. Figure 11 presents a visual comparison between 100 percent pure RGCT (USCL-01) and 69 percent RGCT plus admixture of YSCT and RBT (USCL-15). These two fish have many of the same observable characteristics, highlighting the importance of these types of genetic analyses in assuring the purity of the stock in native trout fisheries.

\section{Lower Sand Creek Lake}

\section{Physical Conditions}

Lower Sand Creek Lake is in a basin nearly at tree line, slightly lower in elevation than Upper Sand Creek Lake $(11,480 \mathrm{ft})$, Approximately 60 percent of the shoreline on Lower Sand Creek Lake is forested with riparian shading provided by Picea sp. (spruce trees). The west and south shores of the lake are largely boulder/rock scree that fall into the lake from the Tijeras Peak spire.

During the bathymetric survey, Lower Sand Creek Lake was measured at approximately 9 ha in surface area, with a maximum depth of $13.7 \mathrm{~m}$, and an estimated volume of 300 acre-ft (Rogers, 2015) (fig. 12). During the period of the 


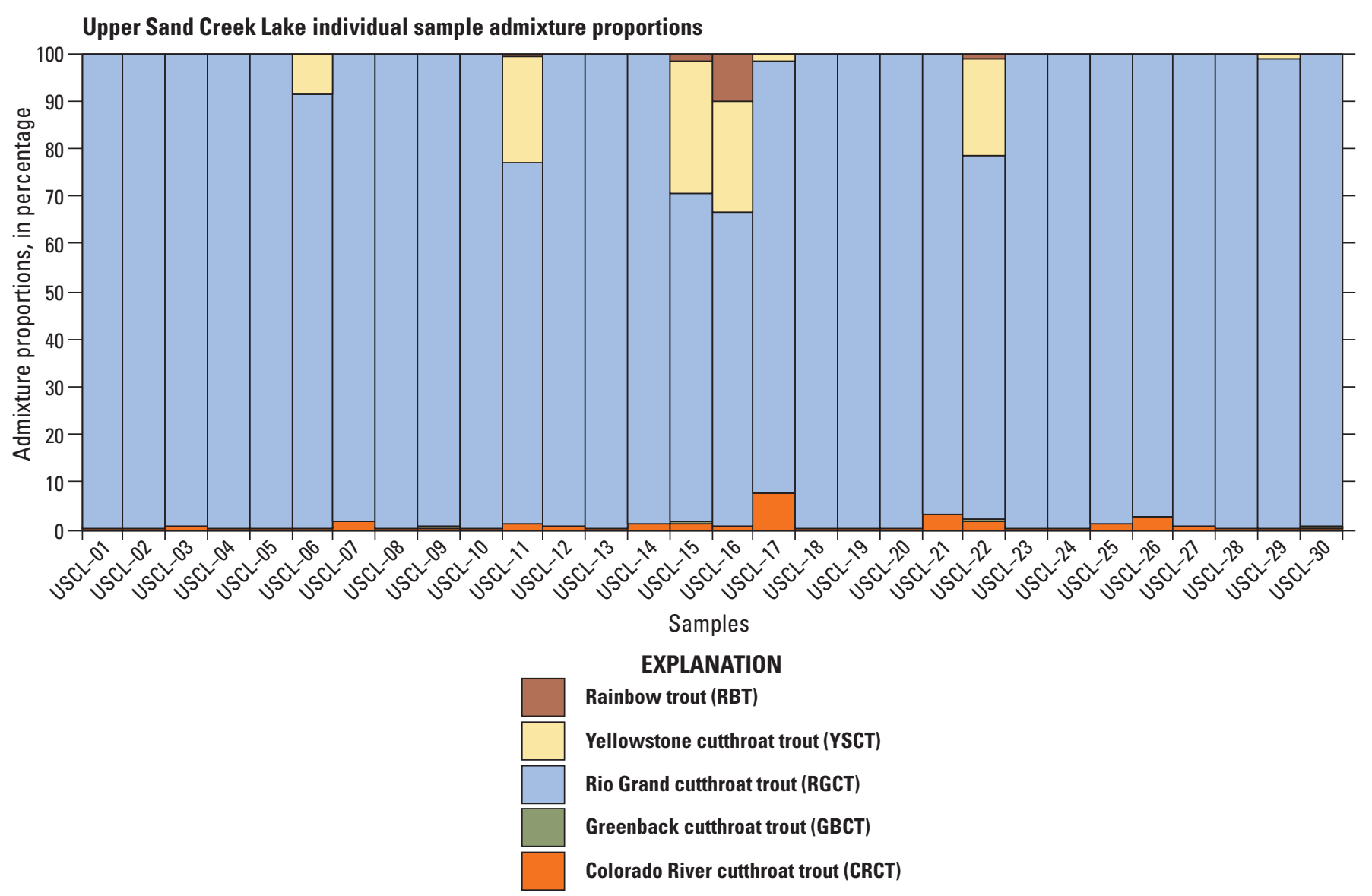

Figure 10. Genetic composition of the fish population within Upper Sand Creek Lake, Great Sand Dunes National Park and Preserve, Colorado. Individual fin clips collected from 30 captured fish were analyzed using amplified fragment length polymorphism (AFLP) tests to distinguish genetic admixture or purity. RBT, Oncorhynchus mykiss (rainbow trout); YSCT, Oncorhynchus clarkii bouvieri (Yellowstone cutthroat trout); RGCT, Oncorhynchus clarkii virginalis (Rio Grande cutthroat trout); GBCT, Oncorhynchus clarkii stomias (greenback cutthroat trout); CRCT, Oncorhynchus clarkii pleuriticus (Colorado River cutthroat trout). Sample ID labeled across x-axis.
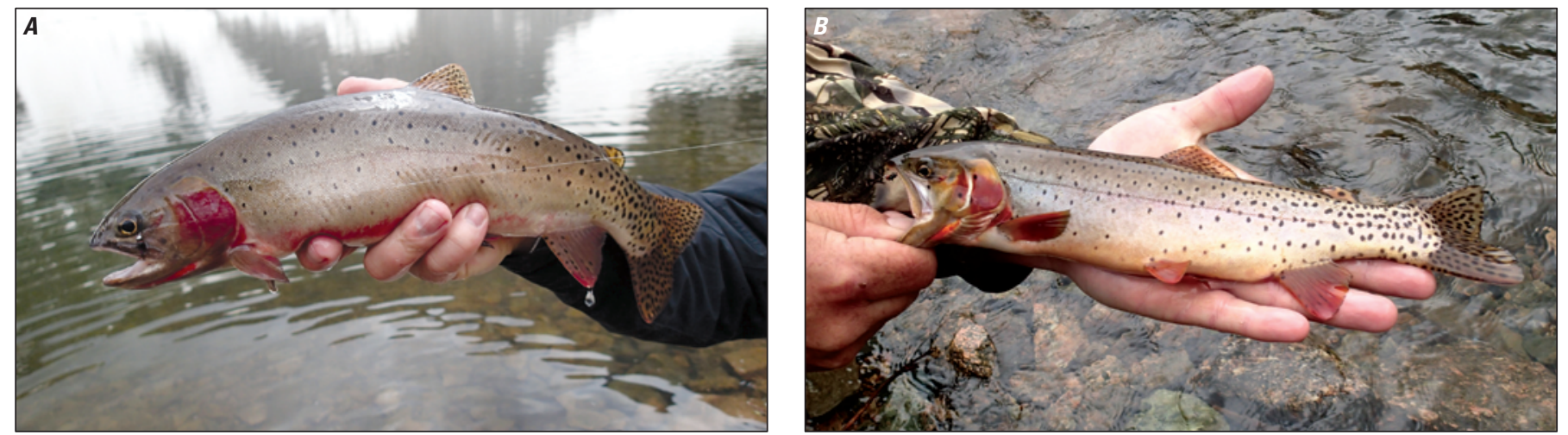

Figure 11. Photographs of two individual fish captured in Upper Sand Creek Lake, Great Sand Dunes National Park and Preserve, Colorado, sampled for genetic analyses. $A, 100$ percent pure Oncorhynchus clarkii virginalis (Rio Grande cutthroat trout, RGCT) (USCL-01). B, 69 percent RGCT plus admixture of Oncorhynchus clarkii bouvieri (Yellowstone cutthroat trout, YSCT) and Oncorhynchus mykiss (rainbow trout, RBT) (USCL-15). These two fish have many of the same observable characteristics (photo credit, Kevin Terry, Trout Unlimited, July 5, 2015). Used with permission. 


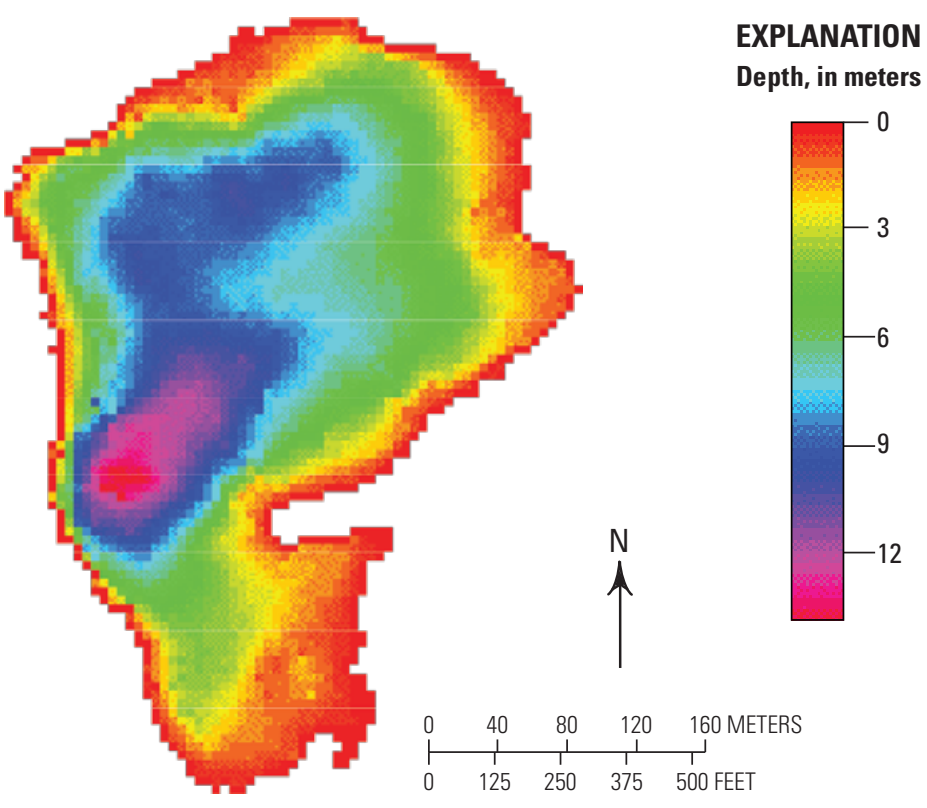

Figure 12. Bathymetric profile of Lower Sand Creek Lake, Great Sand Dunes National Park and Preserve, Colorado (source of image, Rogers 2015). Bathymetry and seasonal stratification profiles are helpful in preparation for piscicide treatment of lentic environments (Finlayson and others, 2010).

survey, ice out at Lower Sand Creek Lake was observed to occur earlier than at Upper Sand Creek Lake (mid- to lateJune), likely due to its lower elevation.

Figure 13 displays how water temperature changed at depth in Lower Sand Creek Lake during the summer of 2015. Although it has a weaker stratification than Upper Sand Creek Lake, Lower Sand Creek Lake clearly establishes a thermocline in mid-July, and the thermocline begins to break up earlier in September. Understanding the depth, strength, and timing of stratification will increase the effectiveness and help define the treatment zone in this lake. Based on this stratification analysis, it appears that Lower Sand Creek Lake is well stratified during the month of August, with fall lake turnover occurring in October.

Multiple tributaries were observed to enter Lower Sand Creek Lake during the survey period, including several tributaries entering from the north and one from the south. Importantly, fish were observed exhibiting spawning behaviors in each of these inlet tributaries, indicating a need for their inclusion in the eventual treatment plan. Water from Lower Sand Creek Lake was observed to flow out of the lake to the northwest. In contrast to Upper Sand Creek Lake, the outlet stream in Lower Sand Creek Lake was observed to have high potential for individual stream fish to return to the lake due to the lack of complexity of the lake outlet.

\section{Biological Conditions}

Results from AFLP analysis of Lower Sand Creek Lake fin clip samples indicated that every fish sampled for genetic analysis (30) in 2015 had at least partial introgression with Yellowstone cutthroat trout genetics (fig. 14). In contrast to Upper Sand Creek Lake, the summary graph of results from Lower Sand Creek Lake AFLP analyses shows that the population is dominated by YSCT signatures, although some samples shared signatures with RBT, RGCT, and CRCT (fig. 14). When compared to stocking history, this genetic composition, and specifically the carryover of previously introduced "Pikes Peak" strain of cutthroat and more recently Haypress RGCT, suggests that lentic reproduction is not limited and is consistently occurring because of the strength of YSCT genetics.

These results indicate that the existing fish population is entirely self-maintaining due to the legacy of "Pikes Peak" genetics, and that current stocking efforts with pure RGCT have had little effect on the sustaining genetic structure. A quantitative population estimate was not conducted as part of this study. However, this genetic analysis predicts strong potential for reproductive success of any future reintroduced population of pure Rio Grande cutthroat. Further, it is plausible that given the productivity of the current hybridized cutthroat trout population, a reclaimed Lower Sand Creek Lake could potentially be used as a backup broodstock of 
Lower Sand Creek Lake Thermocline, Summer 2015

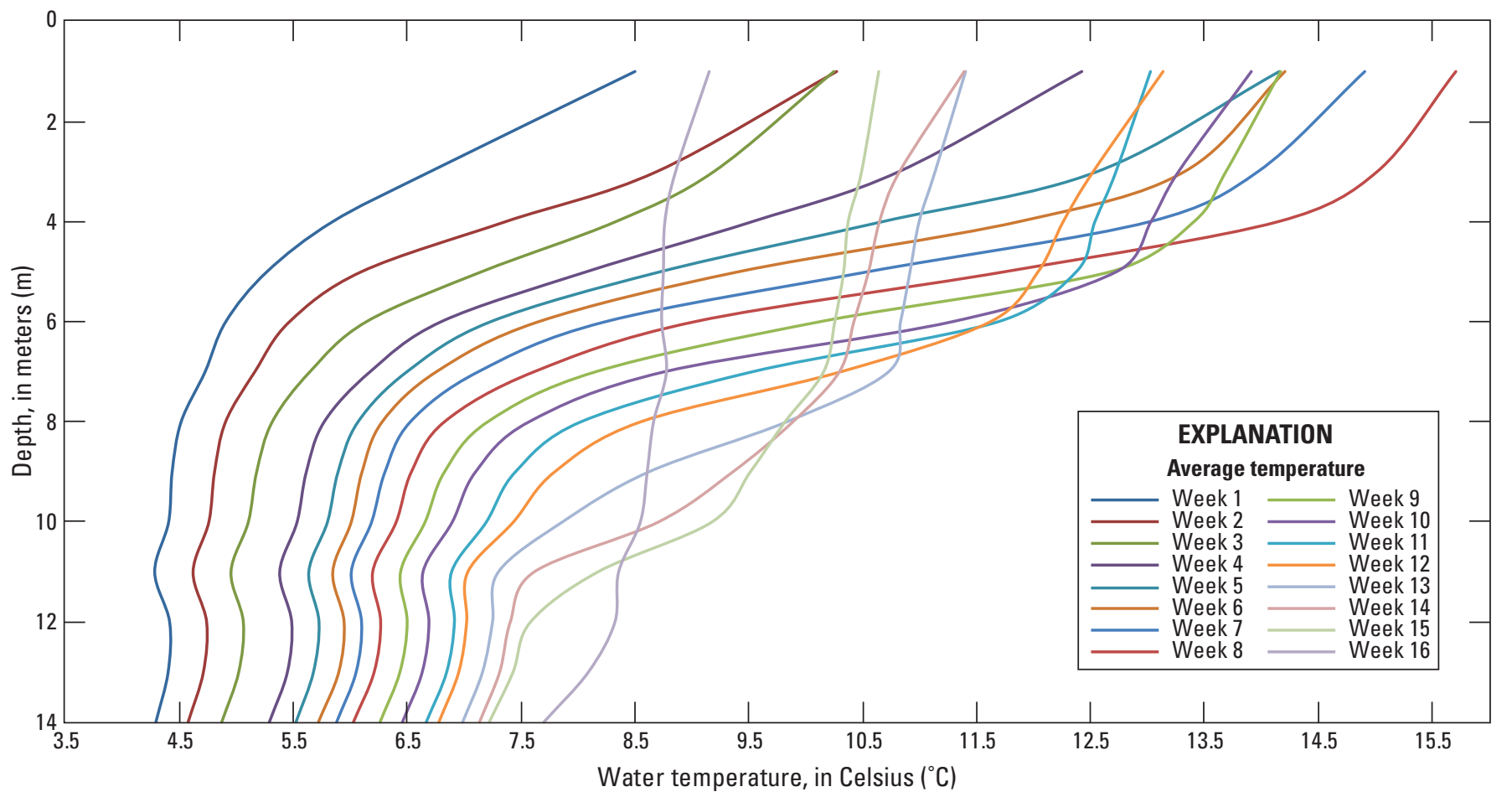

Figure 13. Thermocline graph of Lower Sand Creek Lake, Great Sand Dunes National Park and Preserve, Colorado, shows a strong thermal stratification for most months that the lake is ice free. Lower Sand Creek Lake clearly establishes a thermocline in mid-July, and the thermocline begins to break up earlier in September. Based on this stratification analysis, it appears that Lower Sand Creek Lake is well stratified during the month of August, with fall lake turnover occurring in October. These data help identify the total amount of available fish habitat that needs piscicide treatment (Finlayson and others, 2010).

native RGCT for CPW. Further, the lake is currently utilized as a recreational fishery that allows angler harvest. Because the current genetic structure suggests highly productive recruitment, the lake could likely sustain the current regulations for harvest levels after the reintroduced native RGCT population stabilizes. This can be an important factor for post-treatment management planning and has potential to increase $\mathrm{CPW}$ capacity to resupply RGCT eggs back to hatcheries for future transplant or reintroduction efforts.

Photographs of sampled fish were used to qualitatively compare the phenotypic characteristics of admixed cutthroat trout in Lower Sand Creek Lake. Figure 15 presents a visual comparison between two fish captured in this lake. These photographs illustrate significant observable phenotypic differences in this highly hybridized cutthroat trout population.

\section{Little Sand Creek Lake}

\section{Physical Conditions}

Little Sand Creek Lake at 12,000 ft elevation, has a surface area that encompasses approximately 9.6 acres and approximately $2,625 \mathrm{ft}$ of wetted perimeter. The shoreline is rock scree on the south and east shores, with mixed rock covered by grass and stunted conifers on the west and north banks. Snowmelt water maintains lake water level; however, no defined channels provide surface flows to the lake. The lake levels are sustained by groundwater in the late summer during baseflow and earlier during low snowpack water years. The outlet stream is intermittent and exits the lake at a very steep gradient with waterfall sections and cascades over bedrock substrate.

\section{Biological Conditions}

The fish population in Little Sand Creek Lake appears to consist of low numbers of fish with skewed age structure (only larger, older fish observed). Several attempts to capture fish using various methods proved ineffective. The observed fish appeared to be diseased, or possibly infected with a waterborne fungus (Saprolegnia). The fish appear extremely lethargic, express non-typical cutthroat trout behavior, and appear to have no desire to feed or seek cover.

The intermittent nature of outflow from Little Sand Creek Lake and the extremely steep nature of the outlet stream greatly reduces outward migration of fish, surviving the downstream fall, and ultimately establishing a population downstream of Little Sand Creek Lake. However, the survival of fish through the downstream fall from the lake and establishing a population has potential to compromise restoration 


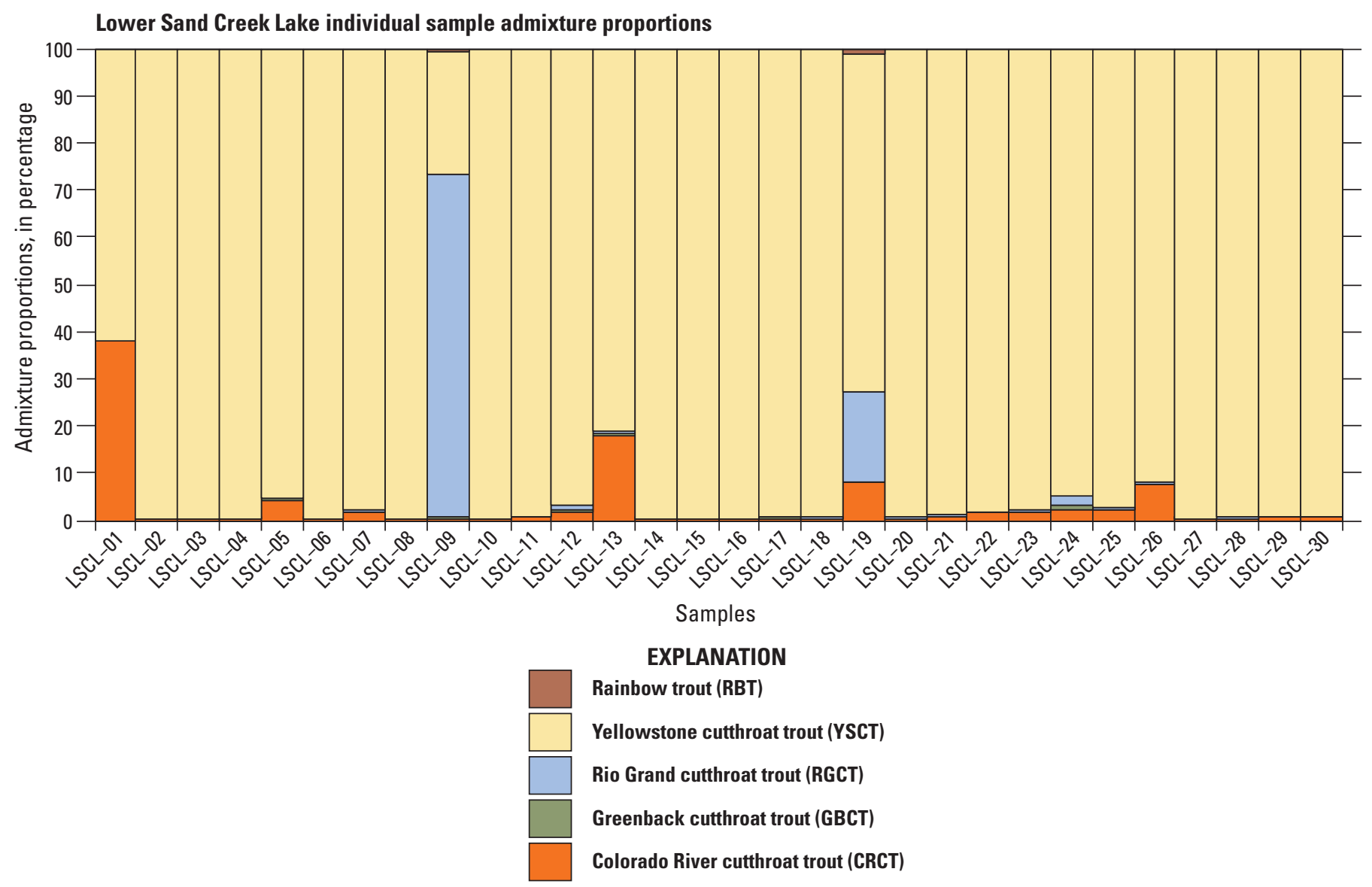

Figure 14. Genetic composition of the fish population within Lower Sand Creek Lake, Great Sand Dunes National Park and Preserve, Colorado. Individual fin clips collected from 30 captured fish were analyzed using amplified fragment length polymorphism (AFLP) tests to distinguish genetic admixture or purity. RBT, Oncorhynchus mykiss (rainbow trout); YSCT, Oncorhynchus clarkii bouvieri (Yellowstone cutthroat trout); RGCT, Oncorhynchus clarkii virginalis (Rio Grande cutthroat trout); GBCT, Oncorhynchus clarkii stomias (greenback cutthroat trout); CRCT, Oncorhynchus clarkii pleuriticus (Colorado River cutthroat trout). Sample ID labeled across x-axis.
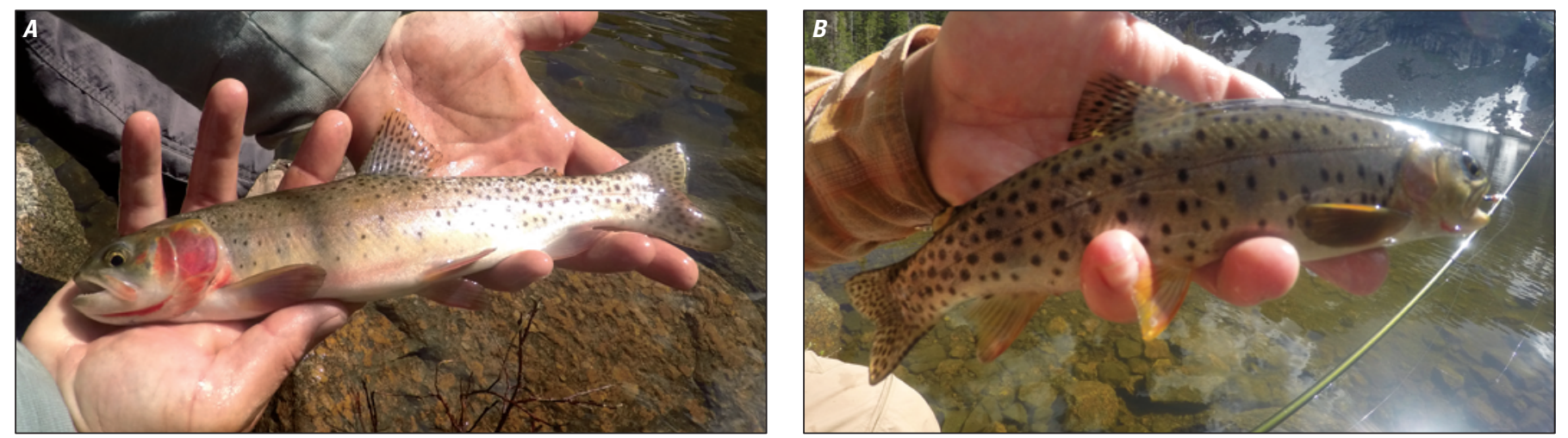

Figure 15. Photographs of two individual fish captured in Lower Sand Creek Lake, Great Sand Dunes National Park and Preserve, Colorado, and sampled for genetic analyses. A, 38 percent Oncorhynchus clarkii pleuriticus (Colorado River cutthroat trout, CRCT) plus admixture of 62 percent Oncorhynchus clarkii bouvieri (Yellowstone cutthroat trout, YSCT) (LSCL-01). B, 100 percent pure Yellowstone cutthroat trout (LSCL-06) These photographs illustrate significant observable phenotypic differences in this highly hybridized cutthroat trout population (photo credit, Andrew Todd, June 29, 2015). 
work through interbreeding with reintroduced RGCT. To help evaluate the severity of risk, genetics tests were run on the three tissue samples collected from Little Sand Creek Lake using the same methods described for Upper and Lower Sand Creek Lakes. The results of this analysis show that all three samples are almost pure Rio Grande cutthroat, likely a result of airplane stocking of the Haypress Lake broodstock maintained by CPW (fig. 16). This result lends further confidence that the current Little Sand Creek Lake trout population is not a significant threat to downstream reclamation projects and should not be a priority for treatment.

The results from that genetic testing support the presumption that the fish population in Little Sand Creek Lake is isolated with no reproduction occurring in the lake. The physical isolation of the Little Sand Creek Lake trout population, in terms of its potential to export fish downstream, was analyzed through extensive downstream electrofishing and eDNA analysis. All lines of evidence support the conclusion that the Little Sand Creek Lake trout population is not self-maintaining through natural reproduction and is physically isolated from the rest of the watershed.

Electrofishing efforts and eDNA samples collected on Little Sand Creek did not produce evidence of fish below the lake and above the probable barrier lower in the watershed (table 4).

\section{Mainstem Sand Creek Stream Physical and Biological Conditions}

\section{Physical Conditions}

The mainstem of Sand Creek originates in the upper reaches of the Sand Creek watershed with flows from Upper and Lower Sand Creek Lakes. Sand Creek gains flow moving downstream from a large number of intermittent and perennial tributaries. Tributaries documented as perennial (that is, no evidence of intermittency or freezing on the STIC loggers)

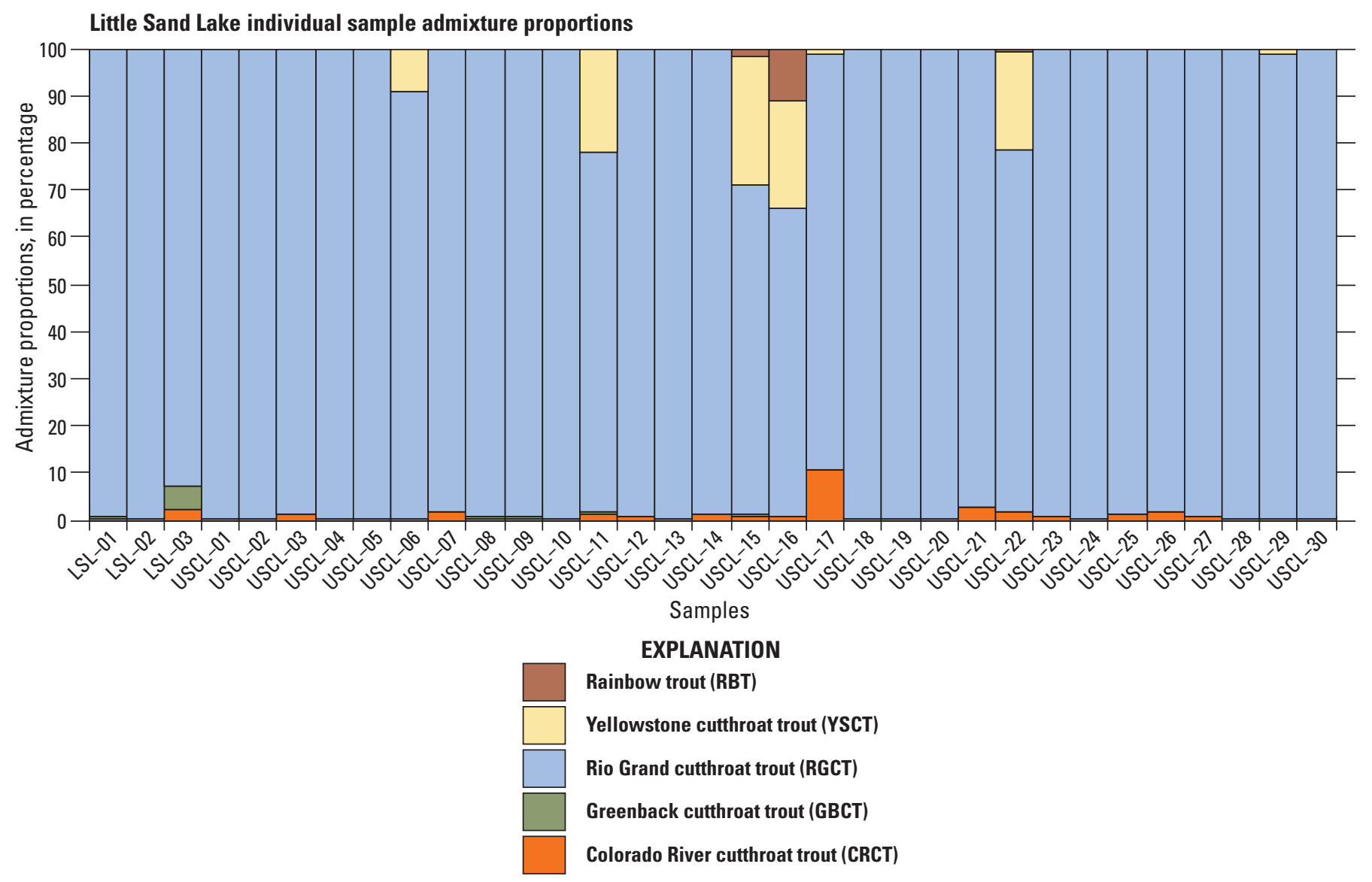

Figure 16. Genetic composition of three fish sampled at Little Sand Creek Lake (LSL-01, LSL-02, and LSL-03), compared statistically to the genetic composition of Upper Sand Creek Lake (USCL-01 through USCL-30) in Great Sand Dunes National Park and Preserve, Colorado. Individual fin clips collected from three captured fish were analyzed using amplified fragment length polymorphism (AFLP) tests to distinguish genetic admixture or purity. RBT, Oncorhynchus mykiss (rainbow trout); YSCT, Oncorhynchus clarkii bouvieri (Yellowstone cutthroat trout); RGCT, Oncorhynchus clarkii virginalis (Rio Grande cutthroat trout); GBCT, Oncorhynchus clarkii stomias (greenback cutthroat trout); CRCT, Oncorhynchus clarkii pleuriticus (Colorado River cutthroat trout). 
Table 4. A summary of fish distribution data collected from visual observation, backpack electrofishing, and eDNA sampling for the Sand Creek watershed, Great Sand Dunes National Park and Preserve, Colorado. Coordinates for site ID can be found in table 1.

[CUTT, General cutthroat trout with known or unknown genetic admixture; BRK, Salvelinus fontinalis (brook trout); RBT, Oncorhynchus mykiss (rainbow trout) n/a, not available; eDNA, environmental deoxyribonucleic acid; NEG, negative; POS, positive]

\begin{tabular}{|c|c|c|c|c|c|}
\hline \multirow{3}{*}{$\begin{array}{l}\text { Site description } \\
\text { Mainstem }\end{array}$} & \multirow{3}{*}{$\begin{array}{l}\text { Site } \\
\text { ID }\end{array}$} & \multicolumn{4}{|c|}{ Fisheries Data } \\
\hline & & \multirow{2}{*}{ Fish observed? } & \multirow{2}{*}{$\begin{array}{l}\text { Electrofishing } \\
\text { (species) }\end{array}$} & \multicolumn{2}{|c|}{ eDNA } \\
\hline & & & & Brook & Cutthroat \\
\hline Sand Creek above Lower Sand Lake outlet creek confluence & $\mathrm{SC} 2$ & CUTT & $\mathrm{n} / \mathrm{a}$ & $\mathrm{n} / \mathrm{a}$ & $\mathrm{n} / \mathrm{a}$ \\
\hline Sand Creek below mainstem beaver pond complex & $\mathrm{SC} 3$ & BRK, CUTT & $\mathrm{n} / \mathrm{a}$ & $\mathrm{n} / \mathrm{a}$ & $\mathrm{n} / \mathrm{a}$ \\
\hline Sand Creek above Little Sand Creek confluence & SC5 & BRK, CUTT & $\mathrm{n} / \mathrm{a}$ & $\mathrm{n} / \mathrm{a}$ & $\mathrm{n} / \mathrm{a}$ \\
\hline Sand Creek below Smith/McKenney Creek confluences & SC6 & BRK, CUTT & $\mathrm{n} / \mathrm{a}$ & $\mathrm{n} / \mathrm{a}$ & $\mathrm{n} / \mathrm{a}$ \\
\hline Sand Creek at bottom & $\mathrm{SC7}$ & BRK, CUTT, RBT & $\mathrm{n} / \mathrm{a}$ & $\mathrm{n} / \mathrm{a}$ & $\mathrm{n} / \mathrm{a}$ \\
\hline \multicolumn{6}{|l|}{ Tributaries } \\
\hline Upper Sand Lake outlet creek —outlet & USL1 & CUTT & $\mathrm{n} / \mathrm{a}$ & $\mathrm{n} / \mathrm{a}$ & $\mathrm{n} / \mathrm{a}$ \\
\hline Lower Sand Lake outlet creek-outlet & LSL1 & CUTT & $\mathrm{n} / \mathrm{a}$ & $\mathrm{n} / \mathrm{a}$ & $\mathrm{n} / \mathrm{a}$ \\
\hline Lower Sand Lake outlet creek-mouth & LSL2 & CUTT & CUTT & $\mathrm{n} / \mathrm{a}$ & POS \\
\hline Bunch Creek-upstream & $\mathrm{BC} 1$ & None observed & NO FISH & $\mathrm{n} / \mathrm{a}$ & NEG \\
\hline Bunch Creek-mouth & $\mathrm{BC} 2$ & CUTT & CUTT $^{1}$ & $\mathrm{n} / \mathrm{a}$ & $\mathrm{NEG}^{2}$ \\
\hline Jones Creek-mouth & $\mathrm{JC} 1$ & None observed & $\mathrm{BRK}^{1}$ & $\mathrm{NEG}^{2}$ & $\mathrm{n} / \mathrm{a}$ \\
\hline Little Sand Creek — upstream & $\mathrm{LSC} 1$ & None observed & NO FISH & NEG & NEG \\
\hline Little Sand Creek - unnamed tributary & LSC3 & None observed & NO FISH & NEG & NEG \\
\hline Little Sand Creek-unnamed tributary & LSC4 & None observed & NO FISH & NEG & NEG \\
\hline Little Sand Creek-mouth & $\mathrm{LSC} 2$ & $\mathrm{BRK}$ & BRK & $\mathrm{n} / \mathrm{a}$ & $\mathrm{n} / \mathrm{a}$ \\
\hline
\end{tabular}

${ }^{1}$ Trout were found in the few pools just above the confluence with Sand Creek.

${ }^{2}$ This sample was taken approximately 100 meters upstream of the confluence with Sand Creek, above an apparent barrier to fish passage.

${ }^{3}$ The first eDNA sample from this location gave a POS result for CUTT. Subsequent samples ( $\mathrm{n}=2$ ) were NEG, and contamination is suspected.

included Upper Sand Creek Lake outlet creek, Lower Sand Creek Lake outlet creek, Bunch Creek, Jones Creek, Little Sand Creek, McKenney Creek, and Smith Creek (table 3).

Discharge measured in the mainstem of Sand Creek in August 2014 and August 2015 showed a high degree of interannual variability (table 3 ). For example, at site SC6, discharge was measured at $21.5 \mathrm{ft}^{3} / \mathrm{s}$ in 2014 and $8.93 \mathrm{ft}^{3} / \mathrm{s}$ in 2015. Streamflow in August 2015 was lower (2-3 times) than in 2014 throughout the Sand Creek watershed. Designing treatment plans for a range of baseflow conditions will likely reduce costs and increase the efficacy of treatment.
Thermal regimes at locations throughout the mainstem of Sand Creek are within the Colorado Water Cold Tier 1 ranges $\left(9{ }^{\circ} \mathrm{C}\right.$ Oct.-May; $17^{\circ} \mathrm{C}$ for June-Sept.) that would be expected to be supportive of salmonids, including Rio Grande cutthroat trout (CDPHE, 2018). Sand Creek mainstem water temperatures fell well below the summertime upper thermal limits $\left(17^{\circ} \mathrm{C}\right.$ ) for sensitive, coldwater species (as defined by the State of Colorado's Cold Stream Tier 1 water temperature criteria; CDPHE, 2018) but also fall above temperatures that have been described to be too cold $\left(7.8^{\circ} \mathrm{C}\right)$ for cutthroat trout, precluding adequate recruitment (Harig and Fausch, 2002). 
The headwater lakes (Upper and Lower Sand Creek Lakes) play a pivotal role in shaping instream thermal conditions in the Sand Creek mainstem during the summer months. During most of the year, the waters in Sand Creek warm with increasing distance downstream. However, during the warmest months of the year (for example, July and August), the uppermost reaches of Sand Creek (that is, site $\mathrm{SC} 1$ ) are warmer than the lower reaches of Sand Creek (for example, sites SC4, SC5, and SC7) (table 2) (fig. 17). The temperature gradient may result from the heating of the large surface area of stratified headwater lakes, contributing warm surface water in the upper reaches (for example, maximum weekly average temperature [MWAT] peaks between 14.5 and $16.6{ }^{\circ} \mathrm{C}$ ) (fig. 17). Downstream cooling may result from the perennial tributaries of Jones Creek, McKenney Creek, and Smith Creek which have cold baseflow temperature peaks between 7.5 and $8.8^{\circ} \mathrm{C}$ in July and August (table 2) (fig. 17).

Several beaver structures were observed in the watershed, mostly occurring near the upper beaver pond tributary (UBP1) site and the lower gradient reaches of mainstem Sand Creek between sites SC2 and SC4. In 2014, field personnel observed a massive beaver complex (approximately $90 \mathrm{ft}$ wide and $9 \mathrm{ft}$ tall) on mainstem Sand Creek near the first stream crossing below Bunch Creek. This structure was no longer present during the following field observations in 2015. Additional large accumulations of avalanche-related debris have been observed over mainstem Sand Creek and over the main trail. This volume of debris and complexity of the beaver structures should be considered when preparing for piscicide treatment.

Many possible physical barriers were observed on mainstem Sand Creek and the tributaries containing fish. These multiple potential barriers do not necessarily limit downstream movement but could eliminate the threat of upstream movement during treatment. One large possible physical barrier on mainstem Sand Creek above Jones Creek is precluding the upstream movement of brook trout. Identifying several key potential barriers could be beneficial in the treatment plan, allowing field personnel to divide the watershed into shorter more manageable reaches during treatment.

\section{Biological Conditions}

The existing fishery within the mainstem of Sand Creek was not quantitatively evaluated as a part of this study for multiple reasons. The presence of trout in the mainstem Sand Creek is already well established, and attributes of the mainstem fishery have been well documented in past investigations (Bramblett and Zale, 2002). Qualitative field observation during the study period revealed large numbers of trout from the headwaters of Sand Creek down to the mouth near the Sand Dunes. Genetic analysis of cutthroat trout within the mainstem of Sand Creek was deemed unnecessary due to hybridization documented in Upper and Lower Sand Creek Lakes (see previous sections) and the direct hydrological nexus of the mainstem of Sand Creek with these lakes.
Previous data for mainstem Sand Creek show BMI communities with strong richness and diversity (Zuellig and others, 2006) (fig. 11). Because mainstem Sand Creek falls entirely within the treatment zone, BMI sampling was not included for the purposes of this study. A post-treatment BMI recovery monitoring effort could present a unique opportunity to further study this watershed and reclamation effort.

\section{Tributaries to Sand Creek Physical and Biological Conditions}

Two notes are relevant to all the tributaries listed in this section. First, baseflow measurements of stream discharge in 2015 were consistently reduced across the basin from the previous year (table 3 ). This shift in discharge may be the result of the interannual variability of precipitation events, snow accumulation, and the timing of runoff. Second, the STIC data record showed no indication of freezing or drying in these tributaries during this study.

\section{Upper Sand Creek Lake Outlet Creek (Sites USL1 and USL2)}

\section{Physical Conditions}

The outlet draining Upper Sand Creek Lake flows approximately 0.3 miles (mi) before reaching its confluence with the mainstem of Sand Creek. This tributary is defined by a steep gradient with several waterfalls and cascading sections. Multiple deep pools (often at the base of waterfalls) were observed within this tributary.

Discharge measured for this tributary to the mainstem of Sand Creek varied between $3.5 \mathrm{ft}^{3} / \mathrm{s}$ in August 2014 and $1.2 \mathrm{ft}^{3} / \mathrm{s}$ in August 2015 (table 3). Water temperatures measured in this tributary are suitable for cutthroat trout survival and recruitment (table 2). Significant cooling of water was observed within this stream from the outlet of Upper Sand Creek Lake (site USL1) to the confluence with Sand Creek (site USL2) during summer months (table 2).

\section{Biological Conditions}

Trout were observed from the outlet of Upper Sand Creek Lake down to the confluence with Sand Creek, primarily in deep pools at the base of waterfalls and cascades. Genetic analysis of cutthroat trout within this outlet draining Upper Sand Creek Lake was deemed unnecessary due to the hybridization (albeit limited) documented in Upper Sand Creek Lake as a part of this study (see above) and the direct hydrological nexus of the outlet creek with the lake.

Previous data for Upper Sand Creek Lake outlet creek show BMI communities with strong richness and diversity (Zuellig and others, 2006) (fig. 11). Because the Upper Sand Creek Lake outlet creek falls entirely within the treatment zone, BMI sampling was not included for the purposes of this study. 


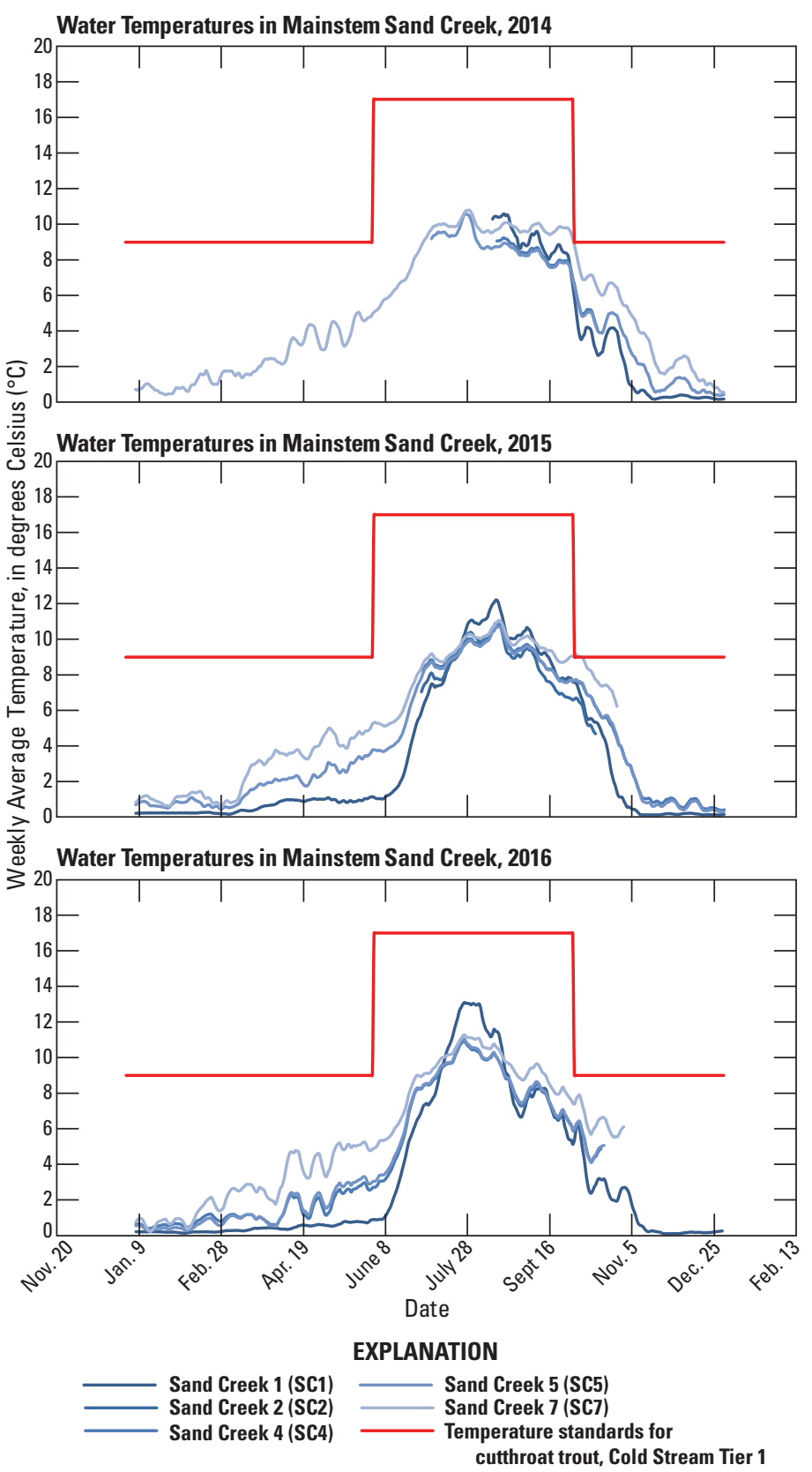

Figure 17. Water temperature data collected in 2014, 2015, and 2016 from mainstem Sand Creek, Great Sand Dunes National Park and Preserve, Colorado. The maximum weekly average temperature (MWAT) is a useful biological metric for estimating habitat suitability and successful recruitment for Oncorhynchus clarkii virginalis (Rio Grande cutthroat trout, RGCT). There are two biologically interesting aspects to the Sand Creek thermal profile. First, temperature data suggest that Sand Creek is an excellent candidate for the reintroduction of RGCT for both habitat and recruitment. Second, because the majority of warming comes from surface water at the high-elevation headwaters lakes during the summertime thermal peak (warmest at site SC1), and water temperature decreases as the stream descends (colder at sites SC5 and SC7). This profile gives Sand Creek somewhat of a thermal buffer in the event of warmer future climate conditions. Logger site locations: SC1, Sand Creek below Upper Sand Lake outlet creek/beaver pond confluence; SC2, Sand Creek above Lower Sand Lake outlet creek confluence; SC4, Sand Creek above Jones Creek confluence; SC5, Sand Creek above Little Sand Creek confluence; SC7, Sand Creek near bottom. 
Sand Creek Characterization Study for Cutthroat Trout, Great Sand Dunes National Park and Preserve, Colo.

\section{Lower Sand Creek Lake Outlet Creek (Sites LSL1 and LSL2)}

Physical Conditions

The outlet for Lower Sand Creek Lake flows approximately $0.9 \mathrm{mi}$ before reaching its confluence with the mainstem of Sand Creek. This tributary is defined by a steep gradient, with multiple waterfalls and cascading sections. Several deep pools (often at the base of waterfalls) were observed within this tributary.

Discharge measured for this tributary to the mainstem of Sand Creek varied between $4.7 \mathrm{ft}^{3} / \mathrm{s}$ in August 2014 and $0.9 \mathrm{ft}^{3} / \mathrm{s}$ in August 2015 (table 3). Water temperatures in this tributary were observed to be suitable for cutthroat trout survival and recruitment (table 2). Significant cooling of water was observed within this stream from the outlet of Upper Sand Creek Lake (site LSL1) to the confluence with Sand Creek (site LSL2) during summer months (table 2).

\section{Biological Conditions}

Trout were present from the outlet of Lower Sand Creek Lake down to the confluence with Sand Creek, primarily in deep pools at the base of waterfalls and cascades. Genetic analysis of cutthroat trout within this outlet creek draining Lower Sand Creek Lake was deemed unnecessary due to the hybridization documented in Lower Sand Creek Lake as a part of this study (see above) and the direct hydrological nexus of the outlet creek with the lake.

Previous data for Lower Sand Creek Lake outlet creek show BMI communities with strong richness and diversity (Zuellig and others, 2006) (fig. 11). Because Lower Sand Creek Lake outlet creek falls entirely within the treatment zone, BMI sampling was not included for the purposes of this study.

\section{Bunch Creek (Sites BC1 and BC2)}

\section{Physical Conditions}

Bunch Creek flows approximately $0.7 \mathrm{mi}$ from a small, shallow lake in its headwaters before reaching its confluence with the mainstem of Sand Creek. Bunch Creek is defined by a steep gradient, with short sections of a more gradual gradient and large pools. Bunch Creek does not appear on most maps, but it drains into Sand Creek just downstream of the outlet creek from Lower Sand Creek Lake.

Discharge measured within Bunch Creek was $3.3 \mathrm{ft}^{3} / \mathrm{s}$ in August 2014 and $0.2 \mathrm{ft}^{3} / \mathrm{s}$ in August 2015 (table 3). Water temperatures measured in this tributary were suitable for cutthroat trout survival and recruitment (table 2). Like other streams, there was a decrease in water temperature from the outlet of Bunch Lake (site BC1) to the confluence with Sand Creek (site $\mathrm{BC} 2$ ) during summer months (table 3 ).

\section{Biological Conditions}

Several trout were observed in Bunch Creek pools just above the confluence with Sand Creek, but nowhere else in the Bunch Creek watershed. Follow-up electrofishing at the mouth of Bunch Creek confirmed that cutthroat trout were present near its mouth, but trout were not captured above an apparent possible barrier to fish passage located approximately $60 \mathrm{ft}$ upstream from the confluence with Sand Creek. A subsequent eDNA sample result from above this apparent barrier was negative for cutthroat trout genetics (table 4).

These collective results indicate that, except for the bottom $60 \mathrm{ft}$, Bunch Creek is currently fishless. During the study period, thermal conditions within Bunch Creek were found to be suitable for trout survival and recruitment, so it is unlikely that water temperature regime is currently limiting the presence of trout. One possible explanation for the current fishless status of Bunch Creek is the presence of a possible physical barrier (for example, waterfall structure) a short distance upstream from the confluence with Sand Creek. Alternatively, August flows in Bunch Creek were measured at a very low $0.2 \mathrm{ft}^{3} / \mathrm{s}$ in 2015, and it is possible that Bunch Creek may undergo streamflow intermittency during extremely dry years.

Because Bunch Creek is fishless (except the bottom 60 $\mathrm{ft}$ ), this reach does not require piscicide treatment. A Bunch Creek MMI score of 53.6 indicates BMI communities with strong richness and diversity with a score above the biotype 2 attainment threshold of 50 (CDPHE, 2017) (fig. 11).

\section{Jones Creek (Site JC1)}

\section{Physical Conditions}

Jones Creek flows approximately $1.1 \mathrm{mi}$ from its headwaters before reaching its confluence with the mainstem of Sand Creek and has a drainage area of 1.2 square miles $\left(\mathrm{mi}^{2}\right)$. Jones Creek is defined by a steep gradient, with short sections of a more gradual gradient.

Discharge measured for Jones Creek was $1.9 \mathrm{ft}^{3} / \mathrm{s}$ in August 2014 and $0.3 \mathrm{ft}^{3} / \mathrm{s}$ in August 2015 (table 3). Water temperatures measured in this tributary were suitable for the survival of cutthroat trout (CDPHE, 2018, Cold Tier 1 standards) but were colder than thresholds reported in the literature to preclude cutthroat trout recruitment (July mean $<7.8^{\circ} \mathrm{C}$; Harig and Fausch, 2002) (table 2).

\section{Biological Conditions}

Trout were not initially observed within the Jones Creek watershed, but follow-up electrofishing at the mouth of Jones Creek revealed that brook trout were present in a few pools near its mouth. Trout were not found above the Sand Creek trail, a possible barrier to fish passage located approximately $100 \mathrm{ft}$ upstream from the confluence with Sand Creek. A subsequent eDNA sample result from above this apparent barrier was negative for brook trout genetics (table 4). 
These collective results indicate that Jones Creek is currently fishless except for the lower $100 \mathrm{ft}$ stream reach. During the study period, thermal conditions within Jones Creek were suitable for trout survival, but not warm enough for cutthroat trout recruitment, so it is unlikely that Jones Creek would be a good candidate for cutthroat trout during the reintroduction phase of reclamation. While there was no evidence of stream intermittency or stream freezing recorded during the study period, low August flows in $2015\left(0.33 \mathrm{ft}^{3} / \mathrm{s}\right)$ suggest that Jones Creek may become intermittent during extremely dry years. Continued monitoring of water temperature and streamflow permanence using STIC loggers is recommended within Jones Creek before any decision is made to introduce fish to its waters.

Because Jones Creek is fishless except the bottom $100 \mathrm{ft}$, most of Jones Creek will not require piscicide treatment. A Jones Creek MMI score of 68.4 indicates BMI communities with exceptional richness and diversity with a score above the biotype 2 high quality water threshold of $>64$ (CDPHE, 2017) (fig. 11).

\section{Little Sand Creek (Sites LSC1, LSC2, LSC3, and LSC4)}

\section{Physical Conditions}

Little Sand Creek flows approximately $2.5 \mathrm{mi}$ from its headwaters before reaching its confluence with the mainstem of Sand Creek and has a drainage area of $2.4 \mathrm{mi}^{2}$. Little Sand Creek and its headwater tributaries are defined by a very steep gradient in the upper reaches, with a more gradual gradient for the last 1.5 miles before the confluence with Sand Creek.

Discharge measured for Little Sand Creek varied between $2.5 \mathrm{ft}^{3} / \mathrm{s}$ in August 2014 and $0.9 \mathrm{ft}^{3} / \mathrm{s}$ in August 2015 (table 3). Water temperatures measured at two locations within this tributary were observed to be suitable for cutthroat trout survival and recruitment (table 2).

\section{Biological Conditions}

Trout were observed only in the lower half mile of Little Sand Creek. Electrofishing in the Little Sand Creek drainage confirmed that brook trout were present throughout the half mile above its confluence with Sand Creek, but trout were not found above a waterfall at this location that serves as a possible barrier to upstream fish passage. Subsequent eDNA sample results at three distinct locations above this possible barrier were negative for both cutthroat trout and brook trout genetics (table 4). These results support the observation that brook trout have not migrated past the likely barrier, as well as the conclusion drawn in the lake section (see above) that cutthroat trout present in Little Sand Creek Lake are not emigrating from the lake to downstream reaches of Little Sand Creek.

These collective results indicate that, except for its final half mile, Little Sand Creek is currently fishless. During the study period, thermal conditions within Little Sand Creek were found to be suitable for cutthroat trout survival and recruitment and as such would be a good candidate for cutthroat trout during the reintroduction phase of this project. There was no evidence of stream intermittency or stream freezing recorded during the study period, and discharge measured in August $2015\left(0.9 \mathrm{ft}^{3} / \mathrm{s}\right)$ suggests that Little Sand Creek remains flowing even during dry years.

The observed macrohabitat in Little Sand Creek is of very high quality (deep pools and channel slope) and is expected to support RGCT should they be introduced to this watershed. A potential treatment/reclamation plan might focus on the removal of brook trout below the apparent waterfall barrier, followed by introduction of native RGCT to the lower gradient sections of Little Sand Creek to its confluence with Sand Creek. Ideally, the treatment/reclamation of Little Sand Creek would happen concurrently with treatment of the mainstem of Sand Creek to avoid repopulation of the lowest reach of Little Sand Creek by fish from the mainstem of Sand Creek.

Because Little Sand Creek has an isolated headwater area and is fishless above this probable physical barrier, most of Little Sand Creek does not require piscicide treatment. A Little Sand Creek MMI score of 67.7 indicates BMI communities with exceptional richness and diversity with a score above the biotype 2 high quality water threshold of $>64$ (CDPHE, 2017) (fig. 11).

\section{Smith Creek (Site SM1)}

\section{Physical Conditions}

Smith Creek flows approximately $2.3 \mathrm{mi}$ from its headwaters before reaching its confluence with the mainstem of Sand Creek and has a drainage area of $1.8 \mathrm{mi}^{2}$. Smith Creek is defined by a steep gradient, with short sections of a more gradual gradient.

Discharge measured for Smith Creek varied between $1.6 \mathrm{ft}^{3} / \mathrm{s}$ in August 2014 and $0.9 \mathrm{ft}^{3} / \mathrm{s}$ in August 2015 (table 3). Water temperatures measured in this tributary were suitable for the survival of cutthroat trout (CDPHE, 2018) but were occasionally colder than thresholds reported in the literature to preclude cutthroat trout recruitment (July mean $<7.8^{\circ} \mathrm{C}$; Harig and Fausch, 2002) (table 2).

\section{Biological Conditions}

No trout were observed throughout the entire Smith Creek watershed during the study period. Follow-up electrofishing at the mouth of Smith Creek concluded that no trout were present in the creek from its mouth to approximately 100 yards (yd) upstream from the confluence with Sand Creek. Subsequent eDNA sample results from the mouth of Smith Creek and Smith Creek upstream were negative for brook trout genetics (table 4).

These collective lines of evidence indicate that Smith Creek is currently fishless. During the study period, thermal conditions within Smith Creek were found to be suitable for 
trout survival, but not warm enough for regular cutthroat trout recruitment, so it is unlikely that Smith Creek would be an ideal candidate for cutthroat trout during the reintroduction phase of this project. Smith Creek has a steep gradient as it enters Sand Creek, so it is possible that trout are physically limited from occupying this tributary, which may also be a factor contributing to its current fishless status.

Because Smith Creek is fishless, it does not require piscicide treatment. A Smith Creek MMI score of 61.6 indicates BMI communities with strong richness and diversity with a score above the biotype 2 attainment threshold of 50 (CDPHE, 2017) (fig. 11).

\section{McKenney Creek (Site MK1)}

\section{Physical Conditions}

McKenney Creek flows approximately $1.5 \mathrm{mi}$ from its headwaters before reaching its confluence with the mainstem of Sand Creek and has a drainage area of $0.8 \mathrm{mi}^{2}$. McKenney Creek is defined by a steep gradient, with short sections of a more gradual gradient.

Discharge measured within McKenney Creek varied between $0.5 \mathrm{ft}^{3} / \mathrm{s}$ in August 2014 and $0.3 \mathrm{ft}^{3} / \mathrm{s}$ in August 2015 (table 3). Water temperatures measured in this tributary were suitable for the survival of cutthroat trout (CDPHE, 2018) but were regularly colder than thresholds reported in the literature to preclude cutthroat trout recruitment (July mean $<7.8^{\circ} \mathrm{C}$; Harig and Fausch, 2002) (table 2).

\section{Biological Conditions}

No trout were observed in the McKenney Creek watershed during the study period visually or through electrofishing. A subsequent eDNA sample result from near the mouth of McKenney Creek was negative for brook trout genetics (table 4).

These collective lines of evidence indicate that McKenney Creek is currently fishless. During the study period, thermal conditions within McKenney Creek were found to be suitable for cutthroat trout survival, but not warm enough for cutthroat trout recruitment, so it is unlikely that McKenney Creek would be an ideal candidate for cutthroat trout during the reintroduction phase of this project. McKenney Creek has a steep gradient as it enters Sand Creek, so it is possible that trout are currently physically limited from occupying this tributary and that also might be a factor contributing to its current fishless status.

Because McKenney Creek is fishless, it does not require piscicide treatment. A McKenney Creek MMI score of 57.0 indicates BMI communities with strong richness and diversity with a score above the biotype 2 attainment threshold of 50 (CDPHE, 2017) (fig. 11).

\section{Cold Creek (Sites CC1 and CC2)}

\section{Physical Conditions}

Cold Creek flows approximately $5.0 \mathrm{mi}$ from its headwaters before reaching its confluence with the mainstem of Sand Creek and drainage area of $5.9 \mathrm{mi}^{2}$. Cold Creek is defined by a relatively gradual gradient in its lower reaches, with steeper gradients in its headwaters. Cold Creek only connects to the mainstem of Sand Creek seasonally, during the runoff period. The rest of the year, Cold Creek becomes a losing stream to the sandy substrates that define it several miles above the confluence with Sand Creek.

Discharge was not measured for Cold Creek as this stream was added late in the study period. Water temperatures in this tributary were only measured in 2016 but were observed to be suitable for cutthroat trout survival and recruitment (table 2).

\section{Biological Conditions}

Fish were not observed in the Cold Creek watershed in 2015, and electrofishing for approximately $1.3 \mathrm{mi}$ upstream from the lower terminus did not produce any fish. Subsequent eDNA sample results at two distinct locations were negative for brook trout genetics but were positive for cutthroat trout genetics at the upper Cold Creek location (table 4).

Because of the 2015 positive cutthroat sample, field crews returned to further survey Cold Creek in 2016. Cold Creek was exhaustively shocked throughout the entirety of the drainage, and multiple eDNA samples were taken at approximately one-mile intervals. No fish were captured or observed, and all 2016 Cold Creek eDNA samples taken tested negative for cutthroat and brook trout DNA (table 4). The 2015 cutthroat trout eDNA sample was likely a false positive, but there are no other indications of unreliable data from site samples and QA/QC samples.

These collective lines of evidence suggest that Cold Creek is currently fishless. During the study period, thermal conditions within Cold Creek were found to be suitable for cutthroat trout survival and recruitment and as such would be a good candidate for cutthroat trout during the reintroduction phase of this project. It is recommended that additional electrofishing/eDNA surveys occur in the Cold Creek watershed prior to completion of the Sand Creek reclamation to its terminus.

\section{Management Summary}

The purpose of this study was to document and characterize the state of the existing fishery within the Sand Creek watershed, and to evaluate key limiting factors for a future native Oncorhynchus clarkii virginalis (Rio Grande cutthroat trout) reintroduction project. Informed by the physical and biological data collected in this study, the Sand Creek watershed can be divided into several distinct categories: 
- Lakes that are good candidates for reclamation and reintroduction of RGCT;

- Lakes that are poor candidates for reclamation;

- Streams that currently have fish and are good candidates for reclamation and reintroduction of RGCT;

- Streams that currently lack fish and may be good candidates for introduction of RGCT; and

- Streams that currently lack fish and are not good candidates for introduction of RGCT.

\section{Lakes that are Good Candidates for Reclamation and Reintroduction of RGCT}

Upper Sand Creek Lake is a good candidate for reclamation and reintroduction of Rio Grande cutthroat trout. While quantitative fisheries surveys were not carried out in Upper Sand Creek Lake as a part of this survey, qualitative data indicate that trout thrive in this lake, as evidenced by the large size of fish. Genetics results from the work done for this report indicate limited persistence of introgression stemming from legacy stocking of "Pikes Peak" strain cutthroat trout. Due to the headwater morphology of Upper Sand Creek Lake, the lake would need to be completely treated to remove that source of introgression from the watershed. Given the limited reproduction evidenced by the genetics analysis, regular stocking of Upper Sand Creek Lake will likely be required to maintain good fish densities in this lake. Fishing restrictions (for example, catch-and-release only) in Upper Sand Creek Lake could also be utilized to limit future stocking necessary in this lake.

Lower Sand Creek Lake is also a good candidate for reclamation and reintroduction of Rio Grande cutthroat trout. While quantitative fisheries surveys were not carried out in Lower Sand Creek Lake as a part of this survey, qualitative data indicate that trout thrive and reproduce in this lake, as evidenced by the large number of fish in this lake. Genetics results from this report indicate sustained persistence of introgression stemming from legacy stocking of "Pikes Peak" strain cutthroat trout. Due to the hydrologic connectivity of the outlet to the greater watershed, Lower Sand Creek Lake would need to be completely treated to remove that source of introgression from the watershed. Given the sustained reproduction evidenced by this study's genetics analysis, regular stocking of Lower Sand Creek Lake will likely not be required to maintain good fish densities. Fishing restrictions (for example, bag limits) in Lower Sand Creek Lake could also be utilized to limit future stocking necessary in this lake.

In both lakes, chemical treatment will require careful consideration of the challenges imposed by the regular establishment of strong lake thermoclines during the summer.

\section{Lakes that are Poor Candidates for Reclamation}

Little Sand Creek Lake is a poor candidate for chemical reclamation for a variety of reasons. Although Little Sand Creek Lake has an existing fishery, this study suggests that the number of fish in this lake is relatively low, and based on limited genetic analysis, the fish that currently inhabit the lake are likely Haypress RGCT. Given the perched nature of Little Sand Creek Lake and the morphology of its outlet, the odds of successful emigration from the lake to downstream reaches is very low. The remote location of Little Sand Creek Lake would make chemical treatment logistics challenging. Management recommendations for Little Sand Creek Lake include waiting for the existing fishery to die out, and then restocking with pure native RGCT.

\section{Streams that Currently Have Fish and are Good Candidates for Reclamation and Reintroduction of RGCT}

Sand Creek has many attributes that make it an ideal watershed for a metapopulation of RGCT. The headwater lakes can act as a persistent source of fish to downstream stream reaches. Physical conditions (for example, cold water temperatures and adequate flows) in Sand Creek make it well situated for long-term sustainability through future variations in climate. The large size of the watershed with multiple viable tributaries buffers Sand Creek against stochastic risks such as drought and wildfire.

The mainstem of Sand Creek from its headwaters to its mouth currently sustains a robust fishery and is a good candidate for reclamation and reintroduction of RGCT. Due to the large and complex nature of this stream as it descends from its headwaters to its mouth, it will likely be most effective to break the larger watershed into sections for a progression of treatments in a downstream direction. The upper Sand Creek watershed has many natural potential barriers that could be utilized as interim breaks in treatment.

Several key tributaries also currently contain fish and are good candidates for reclamation. These include outlets for both Upper and Lower Sand Creek Lakes. Reclamation of these creeks would be an essential component of a greater reclamation strategy, as these creeks connect the headwater lakes with downstream reaches of Sand Creek.

\section{Streams that Currently Lack Fish and may be Good Candidates for Introduction of RGCT}

Bunch Creek, Little Sand Creek, and Cold Creek currently lack fish, but are good candidates for introduction of native RGCT in the future based on their physical characteristics.

Bunch Creek originates from a lake on the western side of the Sand Creek valley and has a similar morphology to 
the outlets of Upper and Lower Sand Creek Lakes. One key difference is that Bunch Lake is very shallow. However, during the study period, Bunch Creek maintained a thermal regime that would be conducive for RGCT survival and recruitment. Further, there was no evidence of drying or freezing of Bunch Creek during this time, including the low flow period of 2015.

Little Sand Creek currently sustains a brook trout fishery in its lowest half mile, downstream of a probable barrier. The water temperatures and flow regime measured in Little Sand Creek over the study period should be conducive to RGCT survival and recruitment.

Water temperature regimes in Cold Creek measured during the study period suggest that its waters would allow RGCT survival and recruitment. One significant uncertainty regarding Cold Creek is the permanence of streamflow in the watershed. Several lines of evidence indicate that fish are not currently present (table 4). Further monitoring or streamflow permanence in Cold Creek is recommended prior to any RGCT introduction efforts.

\section{Streams that Currently Lack Fish and are not Good Candidates for Introduction of RGCT}

Several streams evaluated in this study have physical conditions that would likely preclude the successful establishment of a reproducing population of RGCT. Based on the temperature data collected in this study, Jones Creek, McKenney Creek, and Smith Creek are all likely too cold during the summer months to allow for the accumulation of sufficient degree days for successful RGCT recruitment.

While these tributaries do not appear to have conditions that are suitable for RGCT, they will likely play a key role in the recovery of the mainstem of Sand Creek post-treatment. These tributaries do not currently contain fish (except for the bottom $100 \mathrm{ft}$ of Jones Creek) and will not need to be treated as a part of the reclamation effort. The BMI communities in non-treatment zones can serve as sources for recolonizing mainstem Sand Creek if BMI communities are collaterally affected by the piscicide treatment.

\section{Further Work to Consider}

- Travel time analysis for treatment plan.

- Dissolved oxygen profiles in Upper Sand Creek Lake and Lower Sand Creek Lake.

- Reconnaissance of beaver structures and other accumulated debris ahead of treatment.

- Additional genetics and (or) gill net removal in Little Sand Creek Lake.

- Little Sand Creek Lake bathymetry if considered for future treatment.
- Characterization of possible/potential physical barriers on mainstem Sand Creek to break the watershed into more manageable treatment zones.

- Mainstem Sand Creek BMI recovery monitoring posttreatment.

- Continued monitoring of streamflow permanence (with STIC loggers) is recommended within Bunch Creek, Little Sand Creek, and Cold Creek before any decision is made to introduce fish to these waters.

- Officially name Bunch Creek and Bunch Lake.

\section{References Cited}

Alves, J.E., Patten, K.A., Brauch, D.E., and Jones, P.M., 2008, Range-wide status of Rio Grande cutthroat trout (Oncorhynchus clarkii virginalis) - 2008: Rio Grande Cutthroat Trout Conservation Team Report, Colorado Division of Wildlife, Fort Collins, Colo., 97 p., appendixes. [Also available at http://www.wildlife.state.nm.us/download/ conservation/species/fish/reports-publications/2008-RGCTStatus-Assessment.pdf.]

Behnke, R.J., 1992, Native trout of western North America: Bethesda, Md., American Fisheries Society Monograph no. $6,275 \mathrm{p}$.

Behnke, R.J., 2002, Trout and salmon of North America: New York, N.Y., The Free Press, 384 p.

Bramblett, R.G., and Zale, A.V., 2002, Fish inventories in four park units of the Rocky Mountain network: Bozeman, Mont., U.S. Geological Survey, Department of Ecology, Montana Cooperative Fishery Research Unit, Montana State University. [Also available at ftp.handsontheland.org/grsa/resources/ curriculum/high/docs/four_parks_report_2002.pdf.]

Budy, P., Wood, S., and Roper, B., 2012, A study of the spawning ecology and early life history survival of Bonneville cutthroat trout (Oncorhynchus clarkii utah): North American Journal of Fisheries Management, v. 32, issue 3, p. 436-449. [Also available at https://doi.org/10.1080/0275 5947.2012.675945.

Chapin, T.P., Todd, A.S., and Zeigler, M.P., 2014, Robust, low-cost data loggers for stream temperature, flow intermittency, and relative conductivity monitoring: Water Resources Research, v. 50, issue 8, p. 6542-6548, accessed May 2015, at https://agupubs.onlinelibrary.wiley.com/doi/ pdf/10.1002/2013WR015158. 
Colorado Department of Public Health and Environment (CDPHE), 2017, Methodology to determine use attainment for rivers and streams: Denver, Colo., Water Quality Commission, Aquatic Life Use Attainment: Policy Statement 10-1, p. 3, accessed June 2019, at https://www.colorado.gov/ pacific/sites/default/files/Policy\%2010-1_Appendices.pdf.

Colorado Department of Public Health and Environment (CDPHE), 2018, Regulation no. 36-Classifications and numeric standards for Rio Grande Basin: Denver, Colo., Water Quality Control Commission, 5 CCR 1002-36, p. 7, accessed June 2019, at https://www.sos.state.co.us/CCR/ GenerateRulePdf.do?ruleVersionId $=7881 \&$ fileName $=5 \% 20$ CCR\%201002-36.

Colorado Parks and Wildlife (CPW), 2001, Fish planting receipt for Sand Creek Lakes. Department of Natural Resources, Parks and Wildlife, State of Colorado. Data provided upon request at Colorado Parks and Wildlife Area 17 field office, 0722 South County Road 1 East, Monte Vista, Colo., 81144, or estevan.vigil@state.co.us.

Cowley, D.E., 1993, Strategies for development and maintenance of a hatchery broodstock of Rio Grande cutthroat trout (Oncorhynchus clarkii virginalis): Report to the New Mexico Department of Game and Fish, Professional Services Contract Number 94-516-34, Federal Aid Grant F-60-M, Project 11, 15 p.

Cowley, D.E., and Pritchard, V.L., 2003, Management of Rio Grande cutthroat trout (Oncorhynchus clarkii virginalis) using hatchery stocks: Department of Fishery \& Wildlife Sciences, New Mexico State University.

Finlayson, B., Schnick, R., Skaar, D., Anderson, J., Demong, L., Duffield, D., Horton, W., and Steinkjer, J., 2010, Planning and standard operating procedures for the use of rotenone in fish management-Rotenone SOP manual: Bethesda, Md., American Fisheries Society, 128 p.

Girard, C., 1857, Notice upon the species of the genus Salmo of authors observed chiefly in Oregon and California: Philadelphia, Penn., Proceedings of Academy of Natural Sciences of Philadelphia, v. 9, p. 215-218. [Also available at https://biodiversitylibrary.org/page/1935272.]

Harig A.L., and Fausch, K.D., 2002, Minimum habitat requirements for establishing translocated cutthroat trout populations: Ecological Society of America, v. 12(2), p. 535-551. [Also available at https://esajournals.onlinelibrary.wiley. com/doi/pdf/10.1890/1051-0761\%282002\%29012\%5B0535 \%3AMHRFET\%5D2.0.CO\%3B2.]

Harrelson, C.C., Rawlins, C.L., and Potyondy, J.P., 1994, Stream channel reference sites-An illustrated guide to field technique: Fort Collins, Colo., U.S. Department of Agriculture, Rocky Mountain Forest and Range Experiment Station, Forest Service General Technical Report RM-GTR-245, 61 p. [Also available at https:// doi.org/10.2737/RM-GTR-245.]
McIntyre, J.D., and Rieman, B.E., 1995, Westslope cutthroat trout, chap. 1 of Young, M.K., ed., Conservation assessment for inland cutthroat trout: Fort Collins, Colo., U.S. Department of Agriculture, Rocky Mountain Forest and Range Experiment Station, Forest Service General Technical Report RM-GTR-256, p. 1-15. [Also available at https:// doi.org/10.2737/RM-GTR-256.]

Moore, S., Kulp, M., Rosenlund, B., Brooks, J., and Propst, D., 2008, A field manual for the use of antimycin A for restoration of native fish populations: National Park Service, Natural Resource Report NPS/NRPC/NRR—2008/033, p. 79-81. [Also available at https://irma.nps.gov/DataStore/ DownloadFile/152709.]

National Park Service (NPS), 2006, Restoration of native plant and animal species, in chap. 4.4.2.2 of Natural Resource management, in Management Policies 2006: U.S. National Park Service, p. 45. [Also available at https://www.nps.gov/ policy/MP_2006.pdf.]

Pritchard, V.L., and Cowley, D.E., 2006, Rio Grande cutthroat trout (Oncorhynchus clarkii virginalis) - A technical conservation assessment: U.S. Forest Service, Rocky Mountain Region, Species Conservation Project, Hamilton, Montana, accessed July 2016, at https://www.fs.usda.gov/Internet/ FSE_DOCUMENTS/stelprdb5206803.pdf.

Rio Grande Cutthroat Trout (RGCT) Conservation Team, 2013, Rio Grande cutthroat trout (Oncorhynchus clarkii virginalis) conservation strategy: Colorado Parks and Wildlife, accessed May 2015, at https://cpw.state.co.us/Documents/Research/ Aquatic/CutthroatTrout/2013RGCTConservationStrategy.pdf.

Rogers, K.B., 2015, Mapping the bathymetry of Upper and Lower Sand Creek Lakes-Determining lake volume for reclamation efforts: Steamboat Springs, Colo., Colorado Parks and Wildlife, Aquatic Research, accessed December 2015. Available by request at Colorado Parks and Wildlife, P.O. Box 775777, Steamboat Springs, CO 80477, or kevin.rogers@state.co.us.

Sublette, J.E., Hatch, M.D., and Sublette, M., 1990, The fishes of New Mexico: Albuquerque, New Mex., University of New Mexico Press, 393 p.

The Nature Conservancy (TNC), 2013, Rio Grande cutthroat trout wildfire risk assessment. Overall Risk-Wildfire Risk + Debris Flow Risk. New Mexico Department of Game and Fish, accessed July 2016, at http://www.wildlife.state. nm.us/download/fishing/rio-grande-cutthroat-trout/wildfirerisk/RGCT-Wildfire-Risk-Assessment-Part_1.pdf. 
U.S. Department of the Interior, 2007, The meaning of "In danger of extinction throughout all or a significant portion of its range": U.S. Department of the Interior, Office of the Solicitor, Memorandum to the Director, Fish and Wildlife Service, March 16, 2007, 3 p. [Also available at https://doi. opengov.ibmcloud.com/sites/doi.opengov.ibmcloud.com/ files/uploads/M-37013.pdf.]

U.S. Fish and Wildlife Service, 2002, Endangered and threatened wildlife and plants; candidate status review for Rio Grande cutthroat trout: Federal Register, 50 CFR Part 17, v. 67, n. 112 p. 39936-39947. [Also available at https://www. govinfo.gov/content/pkg/FR-2002-06-11/pdf/02-14569. pdf\#page $=1$.]

U.S. Fish and Wildlife Service, 2003, Policy for evaluation of conservation efforts when making listing decision: Federal Register, 50 CFR chap. IV, v. 68, FR 15100, p. 15100-15115. [Also available at https:/www.govinfo.gov/app/details/ FR-2003-03-28/03-7364/context.]

U.S. Fish and Wildlife Service, 2008, Notice of candidate status review, endangered and threatened wildlife and plants; review of native species that are candidates for listing as endangered or threatened; annual notice of findings on resubmitted petitions; annual description of progress on listing actions: Federal Register 50 CFR Part 17, v. 73, no. 238, p. 27899-27926. [Also available at https://www. federalregister.gov/documents/2008/12/10/E8-28986/ endangered-and-threatened-wildlife-and-plants-review-ofnative-species-that-are-candidates-for.]

U.S. Fish and Wildlife Service, 2014a, Species status assessment report for the Rio Grande cutthroat trout: Albuquerque, New Mex., U.S. Fish and Wildlife Service, Region 2, accessed April 2016, at https://ecos.fws.gov/ServCat/Downl oadFile/161606? Reference $=54121$.

U.S. Fish and Wildlife Service, 2014b, Endangered and threatened wildlife and plants; 12 -month finding on a petition to list Rio Grande cutthroat trout as an endangered or threatened species: Federal Register 50 CFR Part 17, v. 79, issue 190, 79 FR 59140, p. 59140-59150, accessed April 2016, at https:/www.govinfo.gov/app/details/FR-2014-1001/2014-23305.

U.S. Fish and Wildlife Service, 2014c, PECE evaluation Rio Grande Cutthroat trout conservation agreement and conservation strategy and Vermejo Ranch candidate conservation agreement with assurances, 26 August 2014: U.S. Fish and Wildlife Service, accessed July 2016, at www.fws. gov/southwest/es/newmexico/documents/RGCT_PECE_ Evaluation_2014_Final.pdf.

U.S. Geological Survey, 2014, National Hydrography Dataset Plus, Geographic Information System: U.S. Geological Survey, The National Map (TNM) download May 2014, at https://viewer.nationalmap.gov/basic/.
U.S. Geological Survey, 2019, StreamStats output report; Rio Grande Basin, latitude 37.83029 longitude -105.597: U.S. Geological Survey StreamStats, accessed February 1, 2019, at https://streamstats.usgs.gov/ss/.

Young, M.K., Guenther-Gloss, P.M., and Ficke, A.D., 2005, Predicting cutthroat trout (Oncorhynchus clarkia) abundance in high-elevation streams - Revisiting and a model of translocation success: Canadian Journal of Fisheries and Aquatic Science, v. 62, no. 10, p. 2399-2408. [Also available at https://doi.org/10.1139/f05-149.]

Zeigler M.P., Brinkman, S.F., Caldwell, C.A., Todd, A.S., Recsetar, M.S., and Bonar, S. A., 2013, Upper thermal tolerances of Rio Grande cutthroat trout under constant and fluctuating temperatures: Transactions of the American Fisheries Society, American Fisheries Society v. 142, p. 1395-1405, accessed July 2016, at https://afspubs. onlinelibrary.wiley.com/doi/pdf/10.1080/00028487.2013.8 11104.

Zuellig R.E., Kondratieff, B.C., Ruiter, D.E., and Thorp, R.A., 2006, An annotated list of the mayflies, stoneflies, and caddisflies of the Sand Creek basin, Great Sand Dunes National Park and Preserve, Colorado, 2004 and 2005: U.S. Geological Survey Data Series 183. [Also available at https://doi.org/10.3133/ds183.] 


\section{Appendix 1. Summary of Cutthroat Trout Amplified Fragment Length Polymorphism (AFLP) Analysis Procedure and Results}

The following summary is from Pisces Molecular, Boulder, Colorado (http://www.pisces-molecular.com/). Pisces Molecular carried out the genetic composition and eDNA portions of this report.

\section{Summary of Cutthroat Trout AFLP Analysis Procedure}

DNA was extracted from fin clips using a proteinase K tissue lysis and spin-column DNA purification procedure (Qiagen DNeasy).

The DNA was PCR amplified to produce AFLP marker fragments, and the fragments separated and sized on an ABI 3130 sequencer.

Using the program Genemapper 4.0, a genetic fingerprint was produced for each individual sample by scoring for the presence or absence of a standardized set of 119 markers between 50 and 450 base pairs in size generated from reference cutthroat trout populations. Individual genetic fingerprints were checked for inaccuracies in scoring due to low overall peak height, peak size shifting, or rapid decline in peak height of large fragments; aberrant individual fingerprints were eliminated from further analysis.

The genetic fingerprints of individuals in the test population were compared to those found in the reference populations shown below. The program STRUCTURE 2.2 (Falush et.al., 2007) was used to determine similarity or dissimilarity between the test individuals and the reference populations. The similarity or dissimilarity was scored as the admixture proportion(s) in each test individual of genetic background from each of the cutthroat subspecies reference populations. These proportions are expressed as a "q" value for each subspecies. The admixture proportions for the test population as a whole were calculated as the average of the q values for each reference subspecies for each individual in the population.

The cutthroat trout reference populations were chosen and grouped by mtDNA lineage and not necessarily by geographic or historical subspecies classifications. 
Reference populations:

\begin{tabular}{|c|c|c|c|}
\hline & & Pisces & \\
\hline Subspecies & Source & code & $\mathrm{n}$ \\
\hline \multirow{4}{*}{$\begin{array}{l}\text { Colorado River Cutthroat } \\
\text { (CRCT) }\end{array}$} & Williamson Lake \#3 & WLM & 22 \\
\hline & East Fork Piedra & EFP & 20 \\
\hline & South Fork Slater Creek & Sla & 13 \\
\hline & South Fork Parachute Creek & Par & 10 \\
\hline \multirow{3}{*}{$\begin{array}{l}\text { Greenback Cutthroat } \\
(\mathrm{GBCT})\end{array}$} & Severy Creek & $\mathrm{Sev}$ & 26 \\
\hline & West Antelope Creek & ANT & 21 \\
\hline & Bobtail Creek & Bob & 18 \\
\hline \multirow{4}{*}{$\begin{array}{l}\text { Rio Grand Cutthroat } \\
\text { (RGCT) }\end{array}$} & Canones Creek & Can & 29 \\
\hline & Columbine Creek & Clm & 20 \\
\hline & Osier Creek & Osr & 11 \\
\hline & Cuatas Creek & Cts & 10 \\
\hline \multirow{3}{*}{$\begin{array}{l}\text { Yellowstone Cutthroat } \\
\text { (YSCT) }\end{array}$} & Dog Creek & Dog & 19 \\
\hline & Willow Creek (Lower Salt River) & WIL & 14 \\
\hline & Lehardy Rapids & Leh & 12 \\
\hline \multirow{7}{*}{$\begin{array}{l}\text { Rainbow Trout } \\
\text { (RBT) }\end{array}$} & Colorado River Rainbow (G. Schlisler) & CRR & 10 \\
\hline & Bellaire & BEL & 9 \\
\hline & Eagle Lake & ELR & 9 \\
\hline & Erwin & ERW & 9 \\
\hline & Fish Lake & FLR & 9 \\
\hline & Kamloop & KAM & 9 \\
\hline & Tasmanian & TAS & 9 \\
\hline
\end{tabular}

\section{Reference Cited}

Falush, D., Stephens, M., Pritchard, J.K., 2007, Inference of population structure using multilocus genotype dataDominant markers and null alleles: Molecular Ecology Notes, v. 7, issue 4, p. 574-578. [Also available at https://doi.org/10.1111/j.1471-8286.2007.01758.x.]

For more information concerning the research in this report, contact the Center Director, USGS Geology, Geophysics, and Geochemistry Science Center

Box 25046, Mail Stop 973

Denver, CO 80225

(303) 236-1800

Or visit Geology, Geophysics, and Geochemistry Science Center website at https://www.usgs.gov/centers/gggsc 

